Bentham OPEN
CrossMark
Content list available at: www.benthamopen.com/TOBIOTJ/
DOI: $10.2174 / 1874070701610010076$

\title{
Actions of Estrogenic Endocrine Disrupting Chemicals on Human Prostate Stem/Progenitor Cells and Prostate Carcinogenesis
}

\author{
Dan-Ping Hu, Wen-Yang Hu*, Lishi Xie, Ye Li, Lynn Birch and Gail S. Prins \\ Department of Urology, University of Illinois at Chicago, 820 South Wood Street, Suite 132, M/C 955, Chicago, IL, \\ 60612, USA
}

\begin{abstract}
Substantial evidences from epidemiological and animal-based studies indicate that early exposure to endocrine disrupting chemicals (EDCs) during the developmental stage results in a variety of disorders including cancer. Previous studies have demonstrated that early estrogen exposure results in life-long reprogramming of the prostate gland that leads to an increased incidence of prostatic lesions with aging. We have recently documented that bisphenol A (BPA), one of the most studied EDCs with estrogenic activity has similar effects in increasing prostate carcinogenic potential, supporting the connection between EDCs exposure and prostate cancer risk. It is well accepted that stem cells play a crucial role in development and cancer. Accumulating evidence suggest that stem cells are regulated by extrinsic factors and may be the potential target of hormonal carcinogenesis. Estrogenic EDCs which interfere with normal hormonal signaling may perturb prostate stem cell fate by directly reprogramming stem cells or breaking down the stem cell niche. Transformation of stem cells into cancer stem cells may underlie cancer initiation accounting for cancer recurrence, which becomes a critical therapeutic target of cancer management. We therefore propose that estrogenic EDCs may influence the development and progression of prostate cancer through reprogramming and transforming the prostate stem and early stage progenitor cells. In this review, we summarize our current studies and have updated recent advances highlighting estrogenic EDCs on prostate carcinogenesis by possible targeting prostate stem/progenitor cells. Using novel stem cell assays we have demonstrated that human prostate stem/progenitor cells express estrogen receptors (ER) and are directly modulated by estrogenic EDCs. Moreover, employing an in vivo humanized chimeric prostate model, we further demonstrated that estrogenic EDCs initiate and promote prostatic carcinogenesis in an androgen-supported environment. These findings support our hypothesis that prostate stem/progenitor cells may be the direct targets of estrogenic EDCs as a consequence of developmental exposure which carry permanent reprogrammed epigenetic and oncogenic events and subsequently deposit into cancer initiation and progression in adulthood.
\end{abstract}

Keywords: Endocrine disrupting chemicals, estrogen, prostate carcinogenesis, prostate stem/progenitor cells, stem cell division.

\section{INTRODUCTION}

Prostate cancer is the most diagnosed male non-cutaneous malignancy in the Western world [1 - 3]. Many developed Western countries and developing Asian nations are experiencing dramatically increased incidences of this malignancy. However, the mechanism underlying this high disease incidence is not well understood. Established risk factors alone cannot provide clear clues for these unfavorable disease trends. Hormone-dependent initiation and progression of prostate cancer are the basis of hormonal treatment strategies, which have been largely focused on androgen action including androgen ablation and androgen receptor (AR) blockade [4 - 7]. In addition to androgens, there is compelling evidence indicating that estrogens play a central role in prostate development and carcinogenesis, although the mechanisms are not fully understood [8 - 11].

While prostate cancer is well known as a hormone-dependent malignancy, it is now widely accepted that other factors including age, race, genetics, diet, and environmental toxicants impact prostate cancer risk [12].

\footnotetext{
* Address correspondence to this author at the Department of Urology, University of Illinois at Chicago, 820 South Wood Street, Suite 132, Chicago, IL, 60612, USA; Tel: 312-413-1944; Fax: 312-996-9649; Email: wyhu@uic.edu
} 
Endocrine disrupting chemicals (EDCs) are a class of environmental toxicants from naturally-occurring compounds or man-made chemicals that interfere with the endocrine system [13, 14]. In addition to their direct effects in adults, strong evidence indicates significant increased sensitivity to EDCs during the developmental stage, therefore, early-life EDC exposures predispose specific disorders and promote susceptibility to disease with aging, a phenomenon referred to the fetal basis of adult disease $[15,16]$. Epidemiological and animal studies have linked early EDCs exposure to many diseases including immune system disorders, neurodevelopment defects, cardiovascular diseases, metabolic disorders and cancers $[17,18]$. EDCs with estrogenic activity imitate estrogen and have been associated with prostate cancer risk [19]. These xenoestrogens are either natural compounds (e.g. phytoestrogens, inorganic arsenic and cadmium) or synthetic chemicals [e.g. bisphenol A (BPA), dioxins] that can interfere with endogenous estrogen by directly interacting with estrogen receptors (ER). This review will focus on BPA and inorganic arsenic (iAs) as examples of estrogenic EDCs.

Adult stem cells are undifferentiated cells found among differentiated cells in adult tissue that can self-renew and differentiate to repair and maintain tissue homeostasis [20,21]. Recent advances in stem cell research indicate that stem cells may be the direct carcinogenic targets and the cells of origin in cancer initiation and progression. Malignant tumors may originate from transformation of resident normal adult stem cells into cancer stem cells, which generate abnormal progeny to initiate the tumor and continuously seed tumor growth [22 - 26]. Strong evidence support the existence of both normal and cancer stem cells in human prostate, although prostate stem cells are AR negative, they respond to estrogens by expressing ERs [10]. Therefore, it is highly possible that estrogenic EDCs may directly target and reprogram prostate stem cells which are subsequently transformed into cancer stem cells [27,28]. Furthermore, the progression of prostate cancer to androgen independence and the disease relapse are increasingly being attributed to prostate cancer stem cells, which remain untouched by conventional therapies.

To directly address the above questions, we have consequently developed a method to isolate and characterize human prostate stem and progenitor cells that can regenerate normal human prostate tissue in vivo, and subsequently progress into malignancy induced by elevated estrogen in an androgen supported milieu [10, 27 - 29]. These in vitro prostate stem cell assays and in vivo chimeric prostate models with hormonal carcinogenic induction potential can serve as suitable models for examining stem cell perturbations and carcinogenic actions of EDCs on human prostate. We have previously demonstrated that human prostate stem and progenitor cells positively express estrogen receptors (ER $\alpha$, ER $\beta$ and GPR30) and show proliferative response to both estradiol-17 $\left(\mathrm{E}_{2}\right)$ and BPA [10], suggesting that $\mathrm{E}_{2} / \mathrm{BPA}$ may directly target this cell population. Indeed, we recently documented that brief developmental BPA exposure of these cells at environmentally relevant doses increases their carcinogenic susceptibility in vivo [28], similar to an estrogen effect in our previous studies in rodent prostate showing that early-life exposures to environmental estrogens increase susceptibility to prostate carcinogenesis through structural and epigenetic reprogramming [8, 30 - 37]. We therefore hypothesize that, early estrogenic EDCs exposure may result in epigenetic modifications in prostate stem/progenitor cells and reprogram the prostate gland altering their early development, with possible consequences for susceptibility to prostate cancer upon aging.

In this review, we will briefly summarize available evidence for estrogenic EDCs involvement in increased prostate cancer incidence; discuss recent advances in prostate stem cell research, and present evidence for reprogramming of human prostate stem/progenitor cells by estrogenic EDCs using our novel in vitro human prostate stem cell assays and in vivo chimeric prostate models.

\section{ESTROGENIC EDCS AND PROSTATE CARCINOGENESIS}

Prostate cancer is a hormone-regulated malignancy in which hormones are necessary for the growth of cancerous tissues. Despite the extensive research, the involvement of hormone in the earlier steps of carcinogenesis and the cause of prostate cancer is still unclear. Previous studies have shown that estrogens, together with androgens, play an important role in normal prostate development [38]. In rodents, estrogen exposure during fetal life can profoundly alter the developmental trajectory of the gland, sensitizing it to hyperplasia and cancer later in life [8, 33, 39, 40]. Estrogens in combination with androgens have been shown to induce prostate cancer [41, 42]. Furthermore, estrogen production in situ mediates hormonal prostatic carcinogenesis through ER $\alpha$ signaling [43]. More recently, chronic exposure to estrogen alone induced neoplastic transformation of rat prostate epithelial cells [44]. In men, relative serum estrogen levels increase with age as androgen levels decline. Elevated estrogens have been associated with increased prostate cancer risk [45]. Further, estrogen is locally synthesized by testosterone (T) aromatization in prostate stroma [46], while aromatase expression is induced in prostate cancer ( $\mathrm{PCa}$ ) epithelium [46] with expression elevated 30-fold in metastatic 
PCa compared to primary tumors [47, 48]. Recently, estrogen was shown to promote prostate cancer cells invasion through paracrine manner by inducing MMP2 in prostate stromal cells [49]. In addition, estrogen was able to regulate TMPRSS2-ERG fusion gene in patients [50] and modulate oxidative stress in prostate cancer cells [51]. More recently, dietary estrogen was reported to drive pro-carcinogenic inflammation by epigenetic gene silencing [52]. Together, these indicate an important role of estrogen in prostate cancer initiation and progression.

The upsurge in the incidence of prostate cancer in many countries has been attributed partly to the improvement in diagnostic methods and regular population screening, but this alone cannot explain the continuing rise of this disease. Studies of prostate cancer incidence changes in twins and among migrant populations show that environmental factors, including diet and chemical exposures, also contribute to this high incidence disease [53, 54]. EDCs are chemical compounds present in the environment and diet that interfere with normal hormone biosynthesis, signaling, or metabolism [55]. Today, nearly 800 environmental chemicals are identified as EDCs [17]. They are highly heterogeneous and include synthetic chemicals and natural compounds. Synthetic chemicals are industrial solvents/lubricants and their byproducts that structurally resemble natural hormones, such as polychlorinated biphenyls (PCB), polybrominated biphenyls (PBB), dioxins, plastics (e.g. BPA), plasticizers (phthalates), pesticides [methoxychlor, chlorpyrifos, dichlorodiphenyltrichloroethane (DDT)], fungicides (vinclozolin), and pharmaceutical agents [diethylstilbestrol (DES)]. Natural xenoestrogens include metals and phytoestrogens. Cadmium and inorganic arsenic are two metal or metalloid human carcinogens known to interact with ER that function as estrogenic mimics. Phytoestrogens such as genistein and coumestrol are natural chemicals found in human food. They are widely consumed and are present in infant formula [17]. A recent study reported that urinary concentrations of the phytoestrogen genistein were about 500-fold higher in infants that were fed on soy formula compared with infants they were fed on cow's milk formula [56, 57]. This raises the concern for potential endocrine disruption by phytoestrogens.

It has been shown that dietary compounds rich in phytoestrogens can control human prostate cancer growth. Therefore, it is reasonable to evaluate and understand any potential relationship between environmental EDCs and prostate cancer risk. Evidence obtained from in vivo animal studies, in vitro human cells studies, and epidemiological studies indicate the associations between EDCs and prostate carcinogenesis and/or cancer susceptibility. The most compelling data using animal models comes from the established occupational hazards of farming, which showed increased prostate cancer rates is a function of either chronic or intermittent pesticide exposures [58 - 61]. 2,3,7,8tetrachlorodibenzo-p-dioxin (TCDD) is the most toxic dioxin that causes a variety of effects including immunotoxicity, hepatotoxicity, teratogenicity, and tumor promotion [62]. In utero exposure to TCDD in mice interferes with prostate bud patterning and is associated with hyperplastic lesions in aged animals. In humans, it was shown that cadmium has a proliferative action on human prostate cells in vitro through an ER-dependent mechanism [63]. Further, epidemiologic reports have indicated a relationship between cadmium exposure and prostate cancer rates where the mechanism of carcinogenicity appears to be multifactorial [64]. Another epidemiologic study of capacitor manufacturing plant workers highly exposed to PCBs revealed a strong exposure-response relationship for prostate cancer mortality [65]. This supports previous findings of correlations between PCB 153 and 180 and prostate cancer risk in electric utility workers [66, 67]. An Agricultural Health Study is another large epidemiological study among NCI, NIEHS and EPA evaluated more than 55,000 pesticide applicators in North Carolina and Iowa since 1993 and revealed a direct link between methyl bromide exposure and increased prostate cancer rates [60]. In addition, six other common agricultural pesticides including chlorpyrifos, fonofos, coumaphos, phorate, permethrin and butylate were associated with increased prostate cancer in families with history, indicating an interaction between the environment and genetic, which further support the involvement of multiple factors that work synergistically in promoting prostate cancer [60, 68]. Specifically, chlorpyrifos, fonofos and phorate strongly inhibit two major p450s (CYP1A2 and CYP3A4) that metabolize $\mathrm{E}_{2}$, estrone and testosterone in the liver [69, 70]. A similar mechanism of endocrine disruption in vivo has been identified for PCB and polyhalogenated aromatic hydrocarbons (including dioxins, BPA and dibenzofurans) through potent inhibition of estrogen sulfotransferase which effectively elevates bioavailable estrogens in target organs [71, 72], suggesting that exposure to these compounds may disturb hormonal balance by interfering with steroid hormone metabolism which in turn contributes to increased prostate cancer risk.

EDCs are known or suspected to be capable of interfering with hormone receptors, hormone synthesis or hormone conversion. In general, there are two distinct pathways by which EDCs could disrupt hormone action: 1) a direct action on a hormone-receptor complex, for example BPA binds and activates estrogen receptors [73]; and 2) a direct action on a target protein that controls specific aspects of hormone delivery to the specific place at a specific time, such as repression of class I transcription by cadmium is mediated by the protein phosphatase 2A [74]. EDCs exhibit similar 
characteristics as hormones and often interfere with all processes controlled by hormones. They can exert effects on more than estrogen, androgen and thyroid hormone action. The precise mechanisms by which the chemicals induce the carcinogenic process remain to be resolved. However, in the context of current understanding of the etiology of the disease, chemicals with androgenic, anti-androgenic and estrogenic activities are likely to be relevant. Specifically, there is good evidence that organochlorine pesticides including trans-chlordane, chlordecone, and trans-nonachlor which are known to be associated with increased prostate cancer risks, have estrogen-like activities [55, 75]. Cadmium also acts as an estrogen mimic, and arsenic is capable of activating the estrogen receptors [76]. TCDD binds to the aryl hydrocarbon receptor (AhR) [62] and crosstalk between AhR and ER $\alpha$ is well established. Activated AhR inhibits ERa activity while ER $\alpha$ has a positive role in AhR signaling [77]. EDCs with estrogenic activity interfere with normal estrogen signaling, which is mediated by two estrogen receptors: ER $\alpha$ and ER $\beta$ [78]. Despite the low binding affinity to ERs, estrogenic EDCs are active at low concentrations which are well within the range of current human and wildlife exposures. While highlighting evidence of EDCs with estrogenic actions, we will discuss in great detail two wellknown estrogenic EDCs: BPA and inorganic arsenic.

\section{BPA AND PROSTATE CARCINOGENESIS}

BPA, one of the highest produced synthetic compound worldwide and an environmental pollutant with estrogenic activity, is commonly used in polycarbonate plastic containers and epoxy resin linings for many food and beverage cans, and in numerous other common household and consumer products. BPA was first synthesized in the 1890s and its estrogenic actions were identified later in 1936 [79]. BPA is so widespread in its use that there is prevalent human exposure. Although BPA has long been thought to be not persistent, recent evidence suggests longer half-lives [80]. Importantly, BPA is rapidly metabolized to BPA-glucuronide which is not hormonally active. conjugated BPA was detected in the urine of $93 \%$ of the U.S. population in a screen conducted by the Center for Disease Control [81] with significant higher levels found in infants and children [82 - 85]. Based on concentrations measured in food, daily dietary intakes have been estimated in Europe to be about $11 \mu \mathrm{g} / \mathrm{kg}$ body weight in formula-fed babies using polycarbonate plastic bottles and $1.5 \mu \mathrm{g} / \mathrm{kg}$ body weight in adults. Urine values may accurately reflect the actual exposure and assessment by monitoring urinary excretion of BPA metabolites. BPA has been estimated to be up to $0.16 \mu \mathrm{g} / \mathrm{kg}$ body weight in the US population. Although adult exposures do not necessarily imply earlier exposures in life, especially with EDCs of relatively short half-lives, there are data demonstrating nearly 5-fold higher levels of BPA in amniotic fluid compared with other body fluid, suggesting significant prenatal exposure [86].

A number of BPA effects targeting prostate in animals and human have been extensively investigated. The effects of most concern have been related to the hormonal activity of BPA targeting hormone receptors. BPA has a core structure resembling natural estrogen. We have found that prostate stem/progenitor cells express estrogen receptors and have shown response to $\mathrm{E}_{2}$ as well as BPA, indicating BPA modulation of prostate stem/progenitor population [10, 28]. Acting as a weak estrogen, BPA has a much lower affinity for the estrogen receptors ER $\alpha$ and ER $\beta$ than endogenous estrogen. The relative binding affinity of BPA for and its capacity to activate ER-dependent transcription is approximately 1,000 to 10,000 lower than $\mathrm{E}_{2}$ or diethylstilbestrol (DES) $[87,88]$. However, BPA was capable of activating membrane ERs through non-genomic signaling pathways with an $\mathrm{EC}_{50}$ equivalent to $\mathrm{E}_{2}$, suggesting that in vivo estrogenic activity of BPA may be due to nongenomic activation of ER [89, 90]. Furthermore, BPA activates an estrogen-responsive luciferase reporter at levels that were $50 \%$ of $\mathrm{E}_{2}$ activation [91]. Thus, BPA may have a significantly lower potency than endogenous estrogens in vitro; it is still a full agonist for both ER $\alpha$ and ER $\beta$. More recently, BPA has been shown to bind with high affinity to estrogen-related receptor (ERR-ã), which may be related to its ability to function as a reported endocrine disruptor [92, 93].

Prostate hyperplasia has been described after exposure to BPA [94]. Connection between BPA and prostate carcinogenic potential have also been documented $[95,96]$. The prostate carcinogenic potential of BPA was recently evaluated by an expert panel convened by the EPA and the National Institute of Environmental Health Sciences [91]. Evidence from human prostate cell lines demonstrated that BPA modulate prostate cancer cell proliferation and stimulate progression for tumors with AR mutations. Using transcriptional assays, BPA was found to activate a mutated AR (AR-T877A) that is frequently found in advanced prostate cancers of patients who relapsed after androgen deprivation therapy [95]. Furthermore, BPA exposure led to unscheduled cell cycle progression and cellular proliferation in the absence of androgen in LNCaP cells that expressed this mutant AR. Because BPA had no impact on wild-type AR, these findings demonstrate that the common gain-of function AR mutant had attained the ability to utilize BPA as an agonist. Importantly, the BPA effects were greatest at lower doses of BPA compared with high-dose 
exposures, which represents a typical biological response of hormonally active compounds. More recently, urinary BPA levels were shown to be an independent prognostic marker in prostate cancer; exposure to BPA correlates with earlyonset prostate cancer and disruption of the centrosome duplication cycle by low-dose BPA may contribute to neoplastic transformation of the prostate [97]. In addition, evidence from rodent models further supported that BPA can influence prostate carcinogenesis. In vivoanalyses of the impact of BPA on human prostate tumor growth and recurrence were performed utilizing a xenograft model [98]. At low doses equivalent to human exposures, prostate tumor size increased after BPA exposure when compared with placebo control mice. Additionally, mice in the BPA cohort demonstrated an earlier rise in prostate-specific antigen (biochemical failure), which indicates that BPA significantly shortened the time to therapeutic relapse. These outcomes underscore the need for further study of the effects of BPA on tumor progression and therapeutic efficacy. Using our rat models, we have shown that transient, neonatal low-dose BPA exposure heightened hormone-drive susceptibility to adult-onset prostate neoplastic response and precancerous lesions in aged rats [30], possibly by developmentally epigenetic reprogramming on carcinogenic risk [96, 99]. Specifically, neonatal Sprague-Dawley rats exposed to $10 \mathrm{ig}$ BPA/kg body weight during the early postnatal period (post-natal days 1, 3 and 5 when the prostate undergoes morphogenesis) significantly increased the incidence and score of adult estrogen-induced prostate intraepithelial neoplasia (PIN), the precursor lesion for prostate cancer, as compared to control rats [8, 30, 96]. These lesions in BPA-exposed rats exhibited high levels of proliferation and apoptosis suggestive of perturbed homeostasis leading to pathological lesions. This model of sensitivity to hormonal carcinogenesis is relevant to humans where relative $\mathrm{E}_{2}$ levels increase in the aging male and may contribute to prostate disease risk [100]. Furthermore, these studies identified alterations in DNA methylation patterns in multiple cell signaling genes in BPA-exposed prostates, suggest that environmentally relevant doses of BPA reprogram, the developing prostate through epigenetic alterations and subsequently result in predisposition to carcinogenesis $[8,96]$. By using our in vivo humanized chimeric prostate renal graft model, We have recently demonstrated that developmental exposure to low dose BPA increases hormonedependent cancer risk in the prostate epithelium derived from human prostate stem/progenitor cells [28]. Our ongoing studies are investigating if BPA modulates prostate stem/progenitor cells by regulating gene transcriptomes through epigenetically reprogramming of histone methylation and small non-coding RNA expression.

\section{ARSENIC AND PROSTATE CARCINOGENESIS}

Inorganic arsenic (iAs) is a metalloid ubiquitously distributed in nature. It is a widespread environmental contaminant and human carcinogen. Humans are thought to be exposed to arsenic primarily through drinking water and inhalation of contaminated dust from coal burning. Many countries today are still facing a potential public health crisis with arsenic-contaminated drinking water [101]. Exposure to arsenic has long been associated with a number of diseases, including non-neoplastic disorders and cancers [102 - 104]. In utero arsenic exposure induces carcinogenesis of skin and oncogenesis at multiple sites within the urogenital system of the adult offspring [76, 105] and whole life arsenic exposure induces lung and liver malignancies in mice [106]. It has also been shown that arsenic has transplacental carcinogenic activity in humans [107]. Fetal stem cells may be the key targets of arsenic during transplacental carcinogenesis [108].

The association between environmental inorganic arsenic exposure and prostate cancer mortality was first shown by an epidemiological study in Taiwanese men in the late 1980s [109]. In the US, increased prostate cancer incidence and mortality in certain populations was also associated with exposure to higher levels of arsenic through drinking water [110]. Several subsequent studies revealed an association between inorganic arsenic exposure and prostate cancer mortality or incidence [76, 111]. However, due to the lack of long term carcinogenic animal studies, the mechanism for the biotransformation of arsenic is not completely understood. Importantly, it has been documented that arsenic may mediate some of these effects through endocrine disruption, specifically through interaction with ER and activation of estrogen-regulated genes $[112,113]$. Thus, it remains a possibility that endocrine disruption by arsenic can contribute to prostate cancer risk and further research on this topic is essential.

It has been shown that chronic iAs exposure in vitro can transform human prostate epithelial cells into a malignant phenotype toward an androgen independent state that produces aggressive carcinoma xenografts in mouse [114 - 116]. Recent stem cell studies showed that chronic arsenic exposure can transformed human prostate WPE-stem cells into cancer stem-like cells [117 - 119]. Interestingly, arsenic-transformed prostate cells can convert nearby normal stem cells into cancer stem cells [120]. Chronic arsenic exposure also caused increased cell survival, DNA damage, and increased expression of mitochondrial transcription factor A in human prostate epithelial cells [121]. Oxidative stress is another possible mechanism for arsenic action on inducing toxicity and carcinogenesis [122]. A further report indicated a role of arsenic-induced DNA methylation in oxidative DNA damage and a carcinogenic phenotype as evaluated by 
invasiveness, colony formation and secretion of MMPs [123]. More recently, it was showed that chronic exposure to arsenic and/or estrogen altered the expression of epigenetic regulatory genes by changing global DNA methylation and histone modification patterns in prostate epithelial cells [124]. A follow up study indicated that arsenic and estrogen exposures induced prostate epithelial cells transformation by hypermethylation-mediated silencing of $M L H 1$ [125], a DNA mismatch repairing gene, suggesting a possible common epigenetic regulation pathway in the oncogenic event induced by arsenic and estrogen. In addition, arsenic was shown to preferentially activates the Ras/ERK pathway during malignant cell transformation in prostate epithelium, thus, it is likely to say that membrane ERs are involved. Further, several miRNAs were dysregulated in arsenic-transformed prostate epithelial cells which may account for the activation of Ras/ERK signaling, a critical step for arsenic transformation in these cells [126]. The modulation of different signaling pathways by arsenic further support that multiple mechanisms including epigenetic reprogramming are involved in the carcinogenic potential of estrogenic EDCs, which subsequently transform normal stem cells into a cancerous counterpart. Therefore, it becomes essential to further investigate the stem cell modulation by estrogenic EDCs.

\section{HUMAN PROSTATE STEM/PROGENITOR CELLS EXPRESS ESTROGEN RECEPTORS}

\section{Primary Prostate Epithelial Cells Include Small Number of Stem/Progenitor Cells}

Prostate glands are ductal structures composed of three phenotypically and functionally distinct cell types (luminal, basal, and neuroendocrine cells) embedded in a fibro-muscular stroma [127 - 135]. The majority of prostate epithelial cells are cuboidal exocrine luminal cells facing the ductal lumen where they express cytokeratin (CK) 8/18, NKX3.1 and AR. Luminal cells are dependent on androgens for viability and function, producing prostatic secretory proteins such as prostate specific antigen (PSA), and prostate acid phosphatase (PAP) in humans [134, 136 - 138]. Prostate basal epithelial cells are located adjacent to the basal lamina and are identified by expressing p63, CK5 and CK14. Neuroendocrine cells are a minor population scattered throughout the basal layer and are identified by the expression of chromogranin A and synaptophysin [139]. In addition to the three epithelial cell types, there are other rare intermediate cell types expressing prostate stem cell antigen (PSCA) and other prostate stem cell markers, representing the stem/progenitor cell population. [135, 140, 141].

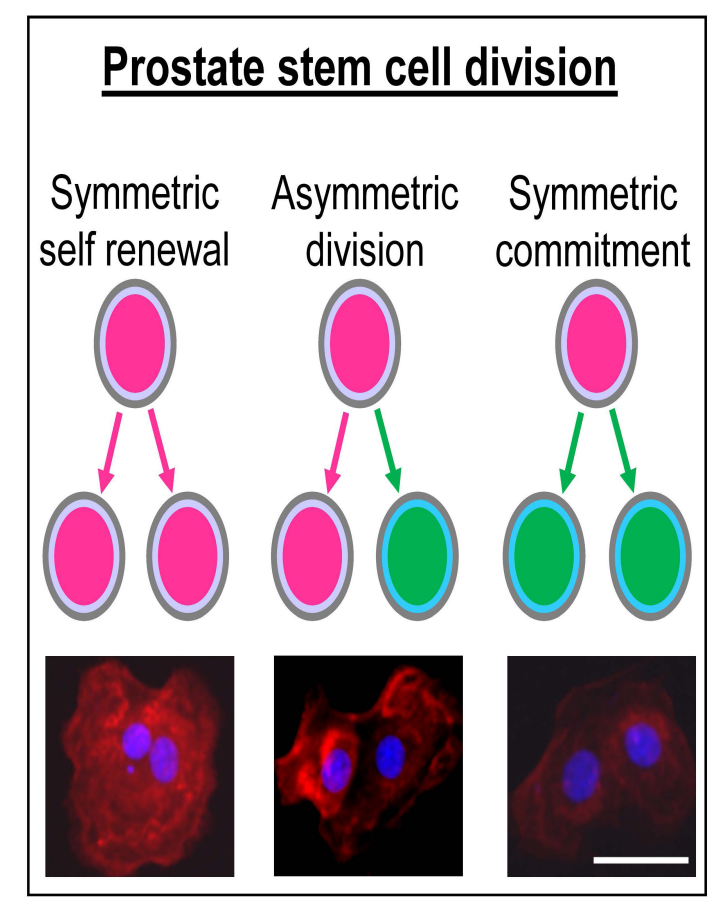

Fig. (1). Prostate stem cell division, symmetric vs asymmetric. Immunolabeling of prostate stem cell marker CD49f in pairs of daughter cells from day 4 prostaspheres indicated 3 different types of stem cell divisions including (A) symmetric renewal, one stem cell gives rise to two identical daughter stem cells $\left(\mathrm{CD} 49 \mathrm{f}^{\text {high }}\right) ;(\mathbf{B})$ asymmetric division, one stem cell gives rise to one daughter stem cell $\left(\mathrm{CD} 49 \mathrm{f}^{\text {high }}\right)$ and one daughter progenitor cell $\left(\mathrm{CD} 49 \mathrm{f}^{\text {low }}\right)$; (C) symmetric commitment, one stem cell gives rise to two differentiated daughter cells $\left(\mathrm{CD} 49 \mathrm{f}^{\text {ow }}\right)$. Prostate stem cells: in pink; prostate progenitor cells: in green; $\mathrm{CD} 49 \mathrm{f}$ : in red. Bar=50 $\mu \mathrm{m}$. 
Adult stem cells are also called somatic stem cells with potential to replenish the cell population and repair damaged tissues to ensure proper function throughout life [21, 26]. Prostate stem cells are adult stem cells identified in both human and rodent prostate glands [141 - 149]. The original evidence of prostate stem cell in gland development was documented in studies using rodent models. Development of the prostate phenotype commences as the urogenital sinus (UGS) epithelial stem and progenitor cells form outgrowths or buds that penetrate into the surrounding UGS mesenchyme [127, 128, 150, 151]. Accumulated prostate stem cells with considerable growth potential have been found in the proximal region of ducts close to the UGS, and the survival of these cells does not require the presence of androgens $[152,153]$.

The lineage hierarchy for prostate epithelial differentiation from stem cells into differentiated basal, luminal and neuroendocrine cells has been documented in the rodent prostate and in isolated human prostate cancer stem cells [130, 135, 144, 145, 154]. Prostate stem cells are relatively growth quiescent, occasionally dividing to self-renew and generate daughter progenitor cells. [22, 147, 155, 156]. Studies across multiple systems as well as the prostate epithelium have characterized three types of stem cell divisions: 1) symmetric division, aka symmetric self-renewal, which generates two identical stem cells; 2) asymmetric division which generates a single self-renewing stem cell and a daughter cell that has entered the earliest stage of differentiation (progenitor cell); and 3) symmetric commitment division whereby a stem cell produces two daughter progenitor cells [157 - 159] (Fig. 1). Different types of stem cell division determine stem cell fate. Unlike the stem cell, the daughter progenitor cell has transit-amplifying capacity through rapid cell divisions. As the progenitor cell proliferative potential is exhausted, it undergoes terminal differentiation.

\section{Isolation and Characterization of Prostate Stem/Progenitor Cells}

Primary culture of prostate epithelial cells is an essential initial step in isolating prostate stem/progenitor cells from normal and diseased human prostate tissues. Fresh prostate tissue from normal organ donors and patients undergoing prostatectomy for prostate cancer or other diseases can be digested, dispersed into single cells and established as primary epithelial cell cultures according to methods characterized by Peehl and others [160]. With advances in stem cell isolation, new approaches are available to isolate stem cell populations with enhanced self-renewal capabilities from primary prostate epithelial cell cultures that contain mixed cell populations. Of these, fluorescence-activated cell sorting (FACS) and 3-D prostasphere cultures are the primary techniques employed [149, 161]. Flow cytometry is widely used for cell sorting by labeling cells with surface CD markers. Many molecules have been identified as prostate stem cell markers including Sca-1, CD133, CD44, CD117, CD49f and Trop2 [143, 147, 162 - 165], and the number continues to grow. While FACS is widely used for prostate stem cell research, there are several disadvantages of cell sorting including a relative low cell yield, need of multiple stem cell markers, and cell damage following labeling and sorting. In terms of functional analysis, prostate stem/progenitor cells can also be assessed using FACS side population analysis. ABCG2 is a member of the ATP binding cassette (ABC) transporters, also known as BCRP (breast cancer resistance protein), which can pump a wide variety of endogenous and exogenous compounds out of cells including Hoechst 33342 [166 - 168]. Widely expressed in a variety of stem cells, ABCG2 is found to be a molecular determinant of the side population phenotype and is recognized as a universal marker of stem cells [166, 167]. The Hoechst exclusion-based side population assay has proven to be a valuable technique for identifying and sorting stem and early stage progenitor cells in a variety of tissues and species. Importantly, prostate stem/progenitor cells and prostate cancer stem cells are defined by increased expression of ABCG2. The prostate stem cell side population was enriched based upon their unique ability to actively efflux Hoechst 33342. Consequently, the side-population assay can be used for the isolation and characterization of putative prostatic stem/progenitor cells [10].

Prostasphere assay is another effective approach for isolating prostate stem cells utilizing a 3-D Matrigel culture system wherein only prostate stem cells are capable of survival and self-renewal forming spheroid structures of stem and early-stage progenitor cells [10, 149, 169 - 171]. Using this Matrigel-slurry culture system, we are able to isolate and expand human prostate stem cells from primary human prostate epithelial cells (PrECs) in vitro. Prostate stem cells are differentially selected and increase in number with about $0.5 \% \sim 2 \%$ of PrECs forming spheroid structures referred to as prostaspheres. Live video imaging was used to capture formation and size increasing of individual prostasphere. By day 4 of culture, prostate stem cells form visible prostaspheres with diameter averages of $30 \mathrm{~mm}$ consisting 20 to 40 cells. Prostaspheres continue to grow and increase in size to an average diameter of $80 \mathrm{~mm}$. At early stages of formation, prostaspheres consist of prostate stem cells and committed progenitor cells that are actively proliferating but have not yet differentiated into cell lineages. From day 10 to 30, cells located in the spheroid center differentiate into a luminal cell phenotype $(\mathrm{CK} 8 / 18+)$ with basal-type cells $(\mathrm{p} 63+)$ in the periphery, forming double-layered prostasphere, 
reaching 100-150 $\mu \mathrm{m}$ in diameter (Fig. 2) [10]. Stem cell fate is determined by the type of stem cell division, either symmetric self-renewal, asymmetric division, or progenitor commitment. Several different assays have been used to monitor stem cell division. By immunostaining using prostate stem cell marker CD49f, we examined the light intensity of CD49f in paired daughter cells from day 4 prostasphere. We were able to distinguish 3 different types of cell divisions including (A) symmetric renewal, two daughter stem cells (CD49 $\mathrm{f}^{\text {high }} / \mathrm{CD} 49 \mathrm{f}^{\text {high }}$ ); (B) asymmetric division, one daughter stem cell (CD49f $\left.{ }^{\text {high }}\right)$ and one daughter progenitor cell $\left(\mathrm{CD} 49 \mathrm{f}^{\text {dow }}\right)$; (C) symmetric commitment, two differentiated daughter cells (CD49 ${ }^{\text {dow }} / \mathrm{CD} 49 \mathrm{f}^{\text {ow }}$ ) (Fig. 1). Furthermore, we have previously demonstrated that human prostate stem and progenitor cells positively express estrogen receptors (ER $\alpha$, ER $\beta$ and GPR30) [10]. qPCR analysis revealed that ER $\beta$ expression increased in days 30 prostasphere as compared to days 7 prostasphere. This was accompanied by increase of prostate luminal cell markers including CK18, HOXB13, NKX3.1, AR, PSA and SOX9, and decrease of stemness gene SOX2, indicating a correlation between ER $\beta$ expression and the induction of luminal cell gene expression. Direct comparison with stem cells sorted by flow cytometry has shown that only prostate stem cells that express Trop2, CD44, and CD49f markers exhibit sphere-forming capacity in a 3-D culture system [141]. The major advantages of the prostasphere assay are the functional isolation of prostate stem/progenitor cells and the expansion capability of the stem/progenitor cell number in vitro which provides multiple research opportunities including analysis of growth and differentiation regulation.

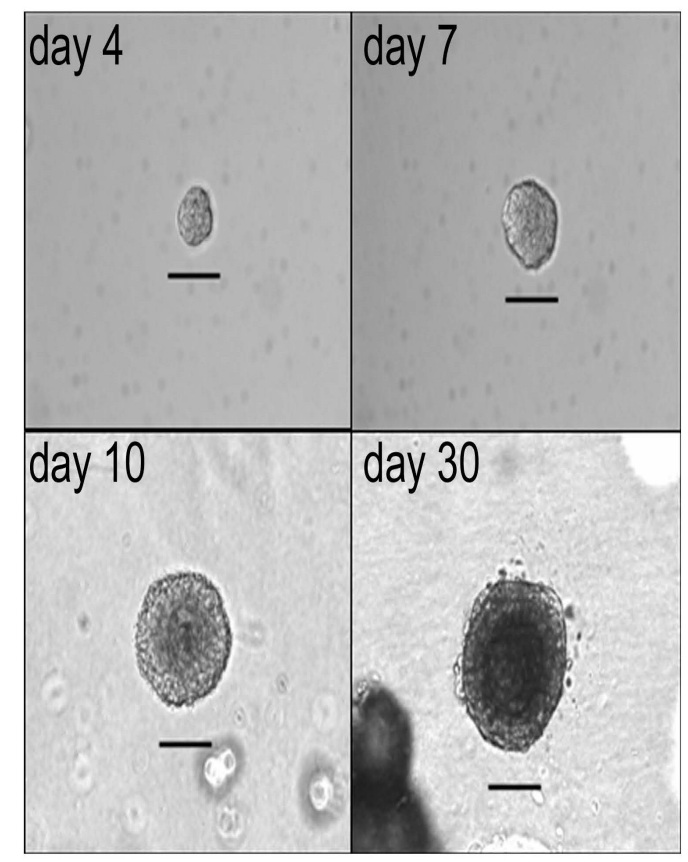

Fig. (2). Isolation of prostate stem/progenitor cells using 3-D prostasphere culture. We isolated and expanded human prostate stem/progenitor cells from primary human prostate epithelial cells (PrECs) in vitro. Using a 3-D Matrigel culture system, prostate stem/progenitor cells were differentially selected and increased in number with about $0.5 \% \sim 2 \%$ of PrECs forming spheroid structures referred to as prostaspheres. Live video imaging was used to capture formation and size increase of individual prostasphere. By day 4, prostaspheres were solid and non-canalized with diameter averages of 30-40 $\mu \mathrm{m}$. Day 7 prostaspheres continue to grow and reach an average diameter of 50-80 $\mu \mathrm{m}$. Day 10 prostaspheres grow to $\sim 100 \mu \mathrm{m}$ in size and cells located in the center start to differentiate and form double-layered structures. By day 30, prostaspheres form 100-150 $\mu \mathrm{m}$ in size and the center canalized. Bar $=50 \mu \mathrm{m}$. (Hu et al., 2011).

In addition to stem cell self-renewal, prostate stem cells can differentiate under certain condition. The dysregulation of stem cell differentiation could be one of the early events of cell transformation and carcinogenesis. Studying the effects of EDCs on prostate stem cell differentiation would be a useful model for evaluating their carcinogenic potential.

In our previous studies, we have reported several different strategies to achieve cell differentiation of prostate stem/progenitor cells. We grew cultures of prostasphere for up to 30 days with co-culture of stromal cells and treatment with differentiating factors such as $10 \mathrm{nM}$ dihydrotestosterone (DHT) or $25 \mathrm{ng} / \mathrm{ml}$ hepatocyte growth factor (HGF) [10, $29,140]$. The differentiation of prostasphere cells is characterized by the formation of ductal branches as well as lumen- 
like structures, thus recapitulating events in early prostate growth and differentiation [10]. Differentiation of prostate stem cells is also indicated by increased expression of luminal markers including CK8/18, NKX3.1, AR and PSA as well as basal cell markers CK5 and p63. Recently, we have also found that all-trans retinoic acid (100 nM) can directly drive prostate stem/progenitor cells into a differentiation phenotype as indicated by the early formation of a double layered prostasphere at day 7 as well as the upregulation of CK18 and HOXB13 gene expression representing luminal epithelial cells differentiation [29]. We anticipate that EDCs may interfere with retinoid signaling that directly alter human prostate stem cell differentiation capacity with potentially detrimental outcomes with regards to prostate carcinogenesis.

\section{ACTION OF ESTROGENIC EDCS ON HUMAN PROSTATE STEM/PROGENITOR CELLS}

Accumulating evidences support a central role for estrogens in prostate cancer. The $\mathrm{E}_{2}: \mathrm{T}$ ratio rises with age in men and is associated with increased prostate cancer incidence [172]. Additionally, the estrogen metabolizing gene polymorphisms and elevated urine hydroxy-estrone ratios are associated with a higher prostate cancer risk [173 - 175]. Aromatase expression is increased in prostate cancers upon progression to metastatic disease [89]. Marked alterations in ER expression with cancer progression $[176,177]$ further support the involvement of estrogens in the etiology and progression of this disease. Furthermore, tissue recombinant experiments using pre-initiated, human prostate BPH-1 cells have shown that elevated $\mathrm{E}_{2}$ and $\mathrm{T}$ were able to promote these cells into invasive cancers [42, 178]. Multiple studies over the past several decades using animal models have provided strong evidence of a carcinogenic role for estrogens in the prostate [90, 179 - 181]. However, there is no direct evidence that estrogens initiate prostate cancer in humans. The role of prostate stem cells in hormonal carcinogenesis had not been clarified.

The cell(s) of origin for prostate cancer may include luminal, basal, neuroendocrine, stem and progenitor cells [24, 182 - 184], while normal adult stem cells are involved in tissue maintenance and repair throughout life, increasing evidence indicate that prostate cancers contain cancer stem cells that continuously seed and maintain tumor growth [21, $23,25,185,186]$. Traditional convention therapies eradicate the majority of cancer cells within a prostate tumor, most patients with advanced cancer eventually progress to androgen-independent, metastatic disease that remains essentially incurable by current treatment strategies. Recent evidence has shown that cancer stem cells are a subset of tumor cells that appear to be therapy-resistant and are responsible for maintaining cancer growth which may be the underlying cause of disease relapse [22, 146, 149, 187 - 189]. Thus, understanding the regulation of both normal stem cells and cancer stem cells may provide new insight into the origin and treatment of prostate cancer. Towards this end, identification and characterization of these rare cell populations has been a major research effort during the past decade with marked progress utilizing flow cytometry and prostasphere cultures [141, 162, 190]. Compared to differentiated cells, stem cells stay relative quiescence allowing for a longer life span and are more susceptible to environmental injuries over time and having capacity to transmit their "injury memory" to the differentiated progeny [191]. Since the prostate gland is most susceptible to environmental insults during early development, it is reasonable to predict that prostate stem and early stage progenitor cells may be the primary targets of estrogenic exposures throughout life [10]. Herein, we have employed our established in vitro and in vivo prostate stem cell assays to test whether prostate stem cells are the potential targets of estrogenic EDCs, and to evaluate whether early life exposure to estrogenic EDCs can actually increase the susceptibility to prostate cancer.

We have documented that although negative for AR mRNA and protein, normal human prostate stem/progenitorcells express robust levels of all known ERs, including ER $\alpha$, ER $\beta$, and GPR30, and show proliferative response to $E_{2}$, suggesting that $E_{2}$ may directly target this cell population [10]. Prostate stem cells can undergo selfrenewal or differentiation. Stem cell fate is determined by stem cell division, either symmetric or asymmetric division. Hormones including $\mathrm{E}_{2}$ and estrogenic EDCs may modulate prostate stem cell self-renewal and differentiation through regulation of stem cell division, by interfering the balance of stem cell homeostasis (Fig. 3A). Immortal strand DNA hypothesis proposed by Cairns [192, 193] suggests when stem cells undergo asymmetric division, parental DNA from mother stem cells segregate into one daughter stem cell and the daughter cell acquires newly synthesized DNA becomes a committed progenitor cell. Using BrdU labeling assays we were able to track prostate stem cell division in prostasphere cells. When prostate stem cells undergo asymmetric division, one daughter cell retains BrdU that keeps the stemness phenotype, representing the daughter prostate stem cell. The other daughter cell begins to enter early differentiation and express differentiation marker CK14, which is then a committed prostate basal progenitor cell (Fig. 3B). This novel assay will allow us to directly examine the estrogenic EDCs effect on prostate stem cell division. Using in vitro prostate stem cell assays, we further tested several estrogenic EDCs to determine if they may similarly be 
capable of affecting prostate stem cell self-renewal and/or differentiation capabilities. Interestingly, BPA treatment at 100 and $1000 \mathrm{nM}$ significantly increased the percentage of prostate stem/progenitor cells side population in primary prostate epithelial cells in 3-D prostasphere culture. BPA at $10 \mathrm{nM}$ significantly increased prostasphere number similar to the $\mathrm{E}_{2}$ exposures [28]. Although arsenic at a dose of $5 \mu \mathrm{M}$ inhibited prostasphere formation and decreased prostate stem cell number (Fig. 4A), it stimulated Akt activity in prostasphere cells by increasing pAkt/total Akt ratios, indicating early event of cell transformation (Fig. 4B). Together, these results demonstrate that normal human prostate stem/progenitor cells are responsive to estrogenic EDCs, implicating these cells as direct estrogen targets. These preliminary data suggest that estrogenic EDCs with estrogenic-type actions may target and affect prostate stem/progenitor cells self-renewal and initiate cell transformation perhaps mediated through divergent ERs and other molecular signaling pathways. As stem cell alterations are long lasting, such perturbations may contribute to prostate cancer risk throughout life.

A.

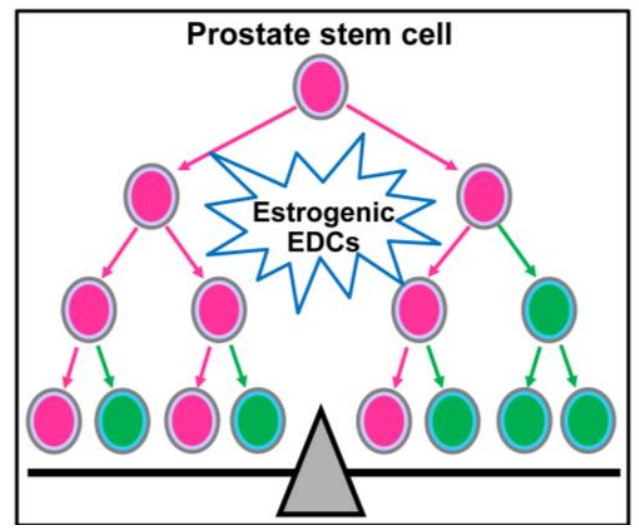

B.

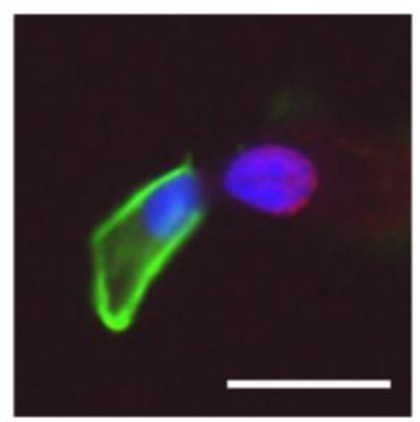

Fig. (3). Possible EDCs effect on prostate stem cell division and its observation by BrdU labeling. (A) Stem cell fate, self-renewal or differentiation, is determined by stem cell division. Estrogenic EDCs may regulate prostate stem cell fate through modulation of prostate stem cell division, either symmetrically or asymmetrically, which will directly interrupt the balance of stem cell pool and tissue homeostasis. Prostate stem cells: pink; prostate progenitor cells: green. (B) PrEC cells were cultured for 6 days in the presence of $1 \mu \mathrm{M}$ BrdU. BrdU labeled PrEC cells were plated into 3-D prostasphere culture. Day 4 prostaspheres were dispersed into single cells and grew on chamber slides overnight to allow cell division. Double immunostaining was performed using BrdU and CK14 antibodies. Prostate stem cells from day 4 prostaspheres undergo three different types of cell division as described in Fig. (2). A representative asymmetric stem cell division is shown. In two paired daughter cells, one cell retaining BrdU (red) represents prostate stem cell; the other cell expressing CK14 (green) is a committed basal progenitor cell. Bar=50 $\mu \mathrm{m}$.

Today, more than ten animal models for prostate carcinogenesis have been described. Evidences from rodent model have shown that early life exposure to EDCs increase prostate cancer susceptibility [19, 32, 96, 194]. However, none of these models used human prostate cells starting with the normal disease free stage. In human, studies are primarily limited to epidemiology studies and studies using human cancer cell lines [33, 76, 97, 195]. Direct connection of EDCs with human prostate cancer risk in vivo would be ideally studied in a model by using normal human cells in animals. The regeneration ability in vivo is another important feature of prostate stem/progenitor cells that can give rise to ductal structures containing both basal and luminal cells. To directly test the carcinogenic potential of estrogenic EDCs, by using the isolated human prostate stem and progenitor cells, we have been able to regenerate a chimeric normal human prostate tissue in vivo and subsequently drive the carcinogenesis progression induced by elevated estrogen in an androgen supported milieu [10]. Formation of human-like prostate tissue was achieved by mixing human prostate stem/progenitor cells with rat embryonic urogenital sinus mesenchyme and grafted under the kidney capsule of nude mice. Normal glandular structures that produce prostate specific antigen (PSA) formed within one month. Recent evidence showed that transformation of prostate stem cells is sufficient for prostate cancer initiation in rodent and human models $[146,183,196]$. Therefore, we further treated the host mice bearing the human-like prostate structures with testosterone and estradiol-17 $\beta(\mathrm{T}+\mathrm{E})$ to induce hormonal carcinogenesis. Prostate epithelial pathology were 
observed over a 1-4 month period, progressing from hyperplasia to prostatic intraepithelial neoplasia (PIN) and adenocarcinoma at a relatively low incidence [10]. This is the first model showing evidence of human prostate stem/progenitor cells as direct estrogen targets and that estrogen, in an androgen-supported milieu, is a carcinogen for human prostate epithelium. The relatively low cancer incidence in this novel system will allow the direct assessment of whether early EDCs exposure are capable of increasing susceptibility of estrogen-induced PIN lesions and prostate cancer in human prostate tissue. Indeed, using this novel humanized model, our recent studies identify for the first time that developmental in vivo exposure of the human prostatic epithelium to low-doses of BPA significantly increases the susceptibility of the human prostate epithelium to hormonal carcinogenesis [28]. Taken together, our in vivo data further supports the possibility that human prostate stem and early progenitor cell populations might be direct targets of estrogenic EDCs increasing the susceptibility to hormone-induced carcinogenesis in aging males.

A.

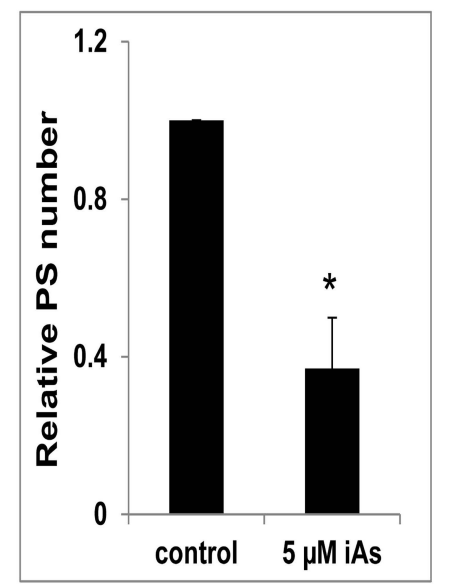

B.

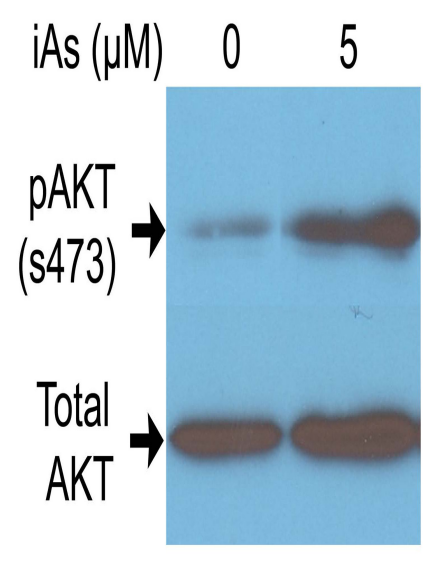

Fig. (4). Effects of $5 \mu \mathrm{M}$ sodium arsenite (iAs) on prostasphere formation and AKT phosphorylation. (A) PrEC cells were cultured in 3-D to form prostaspheres for 7 days in the absence or presence of $5 \mu \mathrm{M}$ iAs. Numbers of prostaspheres (size $>40 \mu \mathrm{m}$ ) were counted. iAs treatment significantly decreased the prostasphere number $(\mathrm{N}=4, \mathrm{P}<0.05)$. (B) iAs treated prostaspheres were harvested for protein isolation and levels of pAKT/total AKT were evaluated by western blot analysis. iAs treatment greatly increased pAKT levels as compared to vehicle. Experiments were repeated three times. A representative blot is shown.

\section{CONCLUSION}

In summary, stem cell fate is critical in maintaining the balance of tissue homeostasis. In addition to their selfrenewal ability, normal prostate stem cells are responsible for the replacement of differentiated prostate epithelial cells within continuously regenerating prostate tissue while terminal differentiated prostate epithelial cells undergo apoptosis. Exposure to EDCs can actually modulate prostate stem cell self-renewal, affect stem cell differentiation and cell apoptosis, as well as drive cell transformation. EDCs may regulate prostate stem cell fate through reprogramming the stem cell division, either symmetrically or asymmetrically (Fig. 5). Our ongoing studies are underway to address this specific question. The new information from our in vitro and in vivo models will gain great interest and will be highly valuable to the field and regulatory communities in terms of presenting strong and compelling evidence for the adverse impact of estrogenic EDCs on humans. These models can contribute to long-term growth in the research enterprise on endocrine disruptors and can serve as a basis for studying carcinogenic effects of estrogenic EDCs. Moreover, it is highly possible that estrogenic EDCs acting through the ER signaling pathway may directly reprogram or transform prostate stem/progenitor cells and subsequently promote tumor initiating capacity. Estrogenic EDCs were recently shown to reprogram organ development by modifying epigenetic mechanisms [96, 197]. Future studies will investigate multiple epigenetic modifications in the human prostate stem/progenitor cells by estrogenic EDCs. Finally, through the novel humanized model systems employing prostate stem/progenitor cells as described, we have potentially provided direct evidences connecting early-life estrogenic EDCs exposures and human prostate carcinogenesis. 


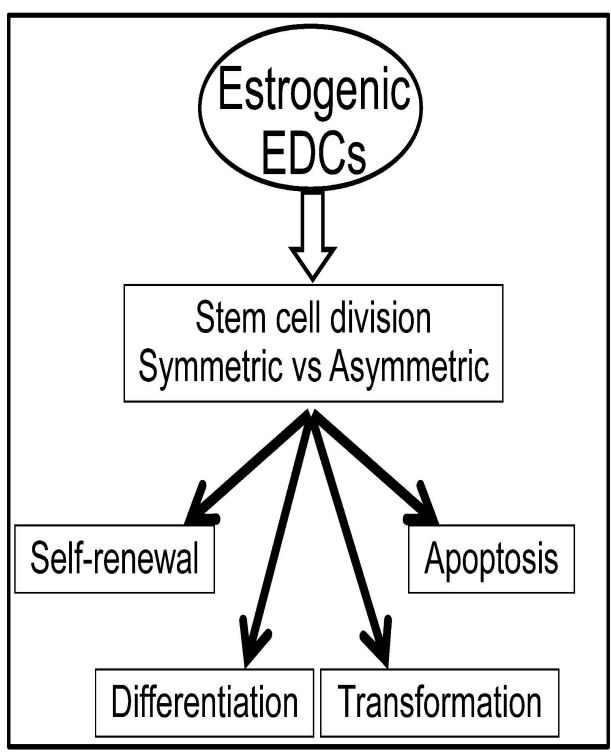

Fig. (5). The maintenance of tissue homeostasis balance is determined by stem cell fate, including stem cell self-renewal, tissue regeneration and repair, differentiation potential and apoptosis. EDCs are able to modulate prostate stem cell self-renewal, affect stem cell differentiation and cell apoptosis, as well as drive cell transformation and subsequently initiate tumorigenesis. Stem cell division, either symmetrically or asymmetrically, is critical in determining stem cell fate. EDCs may regulate prostate stem cell fate through reprogramming the stem cell division, either symmetric or asymmetric.

\section{ABBREVIATIONS}

$\begin{array}{lll}\text { ABCG2 } & = & \text { A member of the ATP binding cassette }(\mathrm{ABC}) \text { transporters } \\ \text { AR } & = & \text { Androgen receptor } \\ \text { BCRP } & = & \text { Breast cancer resistance protein } \\ \text { DHT } & = & \text { Dihydrotestosterone } \\ \text { EDCs } & = & \text { Estrogen receptor } \\ \text { ER } & = & \text { Estradiol } \\ \text { E } & = & \text { Hepatocyte growth factor } \\ \text { HGF } & = & \text { Prostate cancer } \\ \text { PCa } & = & \text { Prostate intraepithelial neoplasia } \\ \text { PIN } & = & \text { Prostate stem cell antigen } \\ \text { PSCA } & = & \text { Prostate specific antigen } \\ \text { PSA } & = & \text { Progesterone receptor } \\ \text { PR } & = & \text { Testosterone } \\ \text { T } & \end{array}$

\section{CONFLICT OF INTEREST}

The authors confirm that this article content has no conflict of interest.

\section{ACKNOWLEDGEMENTS}

This work was supported by NIH grants RC2 ES018758, RO1ES022071 and RO1CA172220.

\section{REFERENCES}

[1] Siegel R, Naishadham D, Jemal A. Cancer Statistics 2013. CA Cancer J Clin 2013; 63: 11-30. [http://dx.doi.org/10.3322/caac.21166]

[2] Jemal A, Center MM, DeSantis C, Ward EM. Global patterns of cancer incidence and mortality rates and trends. Cancer Epidemiol Biomarkers Prev 2010; 19: 1893-907.

[http://dx.doi.org/10.1158/1055-9965.EPI-10-0437] 
[3] Jemal A, Thun MJ, Ries LA, et al. Annual report to the nation on the status of cancer, 1975-2005, featuring trends in lung cancer, tobacco use, and tobacco control. J Natl Cancer Inst 2008; 100: 1672-94. [http://dx.doi.org/10.1093/jnci/djn389]

[4] Huggins C, Hodges CF. Studies on prostatic cancer. I. The effect of castration, of estrogen, and of androgen injection on serum phosphatases in metastic carcinoma of the prostate. Cancer Res 1941; 1: 293-7.

[5] Eisenberger MA, Blumenstein BA, Crawford ED, et al. Bilateral orchiectomy with or without flutamide for metastatic prostate cancer. N Engl J Med 1998; 339: 1036-42. [http://dx.doi.org/10.1056/NEJM199810083391504]

[6] de Bono JS, Logothetis CJ, Molina A, et al. Abiraterone and increased survival in metastatic prostate cancer. N Engl J Med 2011; 364(21): 1995-2005.

[http://dx.doi.org/10.1056/NEJMoa1014618]

[7] Scher HI, Beer TM, Higano CS, et al. Antitumour activity of MDV3100 in castration-resistant prostate cancer: a phase 1-2 study. Lancet 2010; 375(9724): 1437-46. [http://dx.doi.org/10.1016/S0140-6736(10)60172-9]

[8] Prins GS, Birch L, Tang WY, Ho SM. Developmental estrogen exposures predispose to prostate carcinogenesis with aging. Reprod Toxicol 2007; 23: 374-82.

[http://dx.doi.org/10.1016/j.reprotox.2006.10.001]

[9] Ellem SJ, Risbridger GP. Treating prostate cancer: A rationale for targeting local oestrogens. Natl Rev 2007; 7: 621-7. [http://dx.doi.org/10.1038/nrc2174]

[10] Prins GS, Korach KS. The role of estrogens and estrogen receptors in normal prostate growth and disease. Steroids 2008; 73 : 233-44. [http://dx.doi.org/10.1016/j.steroids.2007.10.013]

[11] Hu WY, Shi GB, Lam HM, et al. Estrogen-initiated transformation of prostate epithelium derived from normal human prostate stemprogenitor cells. Endocrinology 2011; 152: 2150-63. [http://dx.doi.org/10.1210/en.2010-1377]

[12] Reuben SH, LaSalle DL, Jr Kripke ML. Annual Report: Reducing Environmental Cancer Risk: What we can do now The President's Cancer Panel. National Institutes of Health; Bethesda, MD. 2010; pp. 1-147.

[13] Birnbaum LS, Fenton SE. Cancer and developmental exposure to endocrine disruptors. Environ Health Perspect 2003; 111: $389-94$. [http://dx.doi.org/10.1289/ehp.5686]

[14] Birnbaum LS. State of the science of endocrine disruptors. Environ Health Perspect 2013; 121 : A107. [http://dx.doi.org/10.1289/ehp.1306695]

[15] Foran CM, Peterson BN, Benson WH. Transgenerational and developmental exposure of Japanese medaka (Oryzias latipes) to ethinylestradiol results in endocrine and reproductive differences in the response to ethinylestradiol as adults. Toxicol Sci 2002; 68: 389-402. [http://dx.doi.org/10.1093/toxsci/68.2.389]

[16] Heindel JJ. The fetal basis of adult disease: Role of environmental exposures--introduction. Birth Defects Res A Clin Mol Teratol 2005; 73: $131-2$. [http://dx.doi.org/10.1002/bdra.20119]

[17] De Coster S, van Larebeke N. Endocrine-disrupting chemicals: associated disorders and mechanisms of action. J Environ Public Health 2012. 2012: 713696

[18] Schug TT, Janesick A, Blumberg B, Heindel JJ. Endocrine disrupting chemicals and disease susceptibility. J Steroid Biochem Mol Biol 2011; 127: 204-15.

[http://dx.doi.org/10.1016/j.jsbmb.2011.08.007]

[19] Bostwick DG, Burke HB, Djakiew D, et al. Human prostate cancer risk factors. Cancer 2004; 101: $2371-490$. [http://dx.doi.org/10.1002/cncr.20408]

[20] Beachy PA, Karhadkar SS, Berman DM. Tissue repair and stem cell renewal in carcinogenesis. Nature 2004; 432: 324-31. [http://dx.doi.org/10.1038/nature03100]

[21] Presnell SC, Petersen B, Heidaran M. Stem cells in adult tissues. Semin Cell Dev Biol 2002; 13: 369-76. [http://dx.doi.org/10.1016/S1084952102000939]

[22] Miki J, Rhim J. Prostate cell cultures as in vitro models for the study of normal stem cells and cancer stem cells. Prostate Cancer Prostatic Dis 2008; 11:32-9.

[http://dx.doi.org/10.1038/sj.pcan.4501018]

[23] Kasper S. Identification, characterization, and biological relevance of prostate cancer stem cells from clinical specimens. Urol Oncol 2009; 27: $301-3$. [http://dx.doi.org/10.1016/j.urolonc.2008.12.012]

[24] Kasper S. Stem cells: The root of prostate cancer? J Cell Physiol 2008; 216: 332-6. [http://dx.doi.org/10.1002/jcp.21489] 
[25] Kasper S. Exploring the origins of the normal prostate and prostate cancer stem cell. Stem Cell Rev $2008 ; 4: 193-201$. [http://dx.doi.org/10.1007/s12015-008-9033-1]

[26] Smith S, Neaves W, Teitelbaum S. Adult versus embryonic stem cells. Treat Sci 2007; 316: 1422-3.

[27] Prins GS, Hu WY. Stem cells and prostate cancer. In: Cramer SD, Ed. Springer LLC. USA: VII 2013; pp. 1-20.

[28] Prins GS, Hu WY, Shi GB, et al. Bisphenol A promotes human prostate stem-progenitor cell self-renewal and increases in vivo carcinogenesis in human prostate epithelium. Endocrinology 2014; 155: 805-17. [http://dx.doi.org/10.1210/en.2013-1955]

[29] Hu WY, Shi GB, Hu DP, Nelles JL, Prins GS. Actions of endocrine disrupting chemicals on human prostate stem/progenitor cells and prostate cancer risk. Mol Cell Endoer 2012; 354: 63-73.

[http://dx.doi.org/10.1016/j.mce.2011.08.032]

[30] Prins GS, Ye SH, Birch L, Ho SM, Kannan K. Serum bisphenol a pharmacokinetics and prostatic responses following oral and subcutaneous exposures in neonatal sprague-dawley rats. Reprod Toxicol 2011; 31: 1-9. [http://dx.doi.org/10.1016/j.reprotox.2010.09.009]

[31] Prins GS, Ho SM. Early life estrogens and prostate cancer in an animal model. J Dev Orig Health Dis 2010; $1: 365-70$. [http://dx.doi.org/10.1017/S2040174410000577]

[32] Prins GS, Tang WY, Belmonte J, Ho SM. Perinatal exposure to oestradiol and bisphenol a alters the prostate epigenome and increases susceptibility to carcinogenesis. Basic Clin Pharmacol Toxicol 2008; 102: 134-8. [http://dx.doi.org/10.1111/j.1742-7843.2007.00166.x]

[33] Prins GS. Endocrine disruptors and prostate cancer risk. Endocr Relat Cancer 2008; 16: 649-53. [http://dx.doi.org/10.1677/ERC-08-0043]

[34] Prins GS, Birch L, Ye SH, Ray V. Estrogen exposure leads to prostate lobe-specific dysplasia and adenomas in the aging rat. Minneapolis, $\mathrm{MN}$ : American Society of Andrology 1996.

[35] Prins GS, Birch L. Neonatal estrogen up-regulates estrogen receptor in prostatic smooth muscle cells and increases extracellular TGF $b_{1}$. Program of the $76^{\text {th }}$ Annual Meeting of the Endocrine Society. Anaheim, CA. 1994.

[36] Prins GS, Woodham C, Lepinske M, Birch L. Effects of neonatal estrogen exposure on prostatic secretory genes and their correlation with androgen receptor expression in the separate prostate lobes of the adult rat. Endocrinology 1993; 132: 2387-98.

[37] Prins GS. Neonatal estrogen exposure induces lobe-specific alterations in adult rat prostate androgen receptor expression. Endocrinology 1992; 130: 3703-14. [http://dx.doi.org/10.1210/en.130.6.3703]

[38] Harkonen PL, Makela S. Role of estrogens in the development of prostate cancer. Steroid Biochem Mol Biol 2004; $92: 297-305$. [http://dx.doi.org/10.1016/j.jsbmb.2004.10.016]

[39] Huang L, Pu Y, Alam S, Birch L, Prins GS. Estrogenic regulation of signaling pathways and homeobox genes during rat prostate development. J Androl 2004; 25: 330-7. [http://dx.doi.org/10.1002/j.1939-4640.2004.tb02796.x]

[40] Ellem SJ, Risbridger GP. The dual, opposing roles of estrogen in the prostate. Ann N Y Acad Sci 2009; 1155: 174-86. [http://dx.doi.org/10.1111/j.1749-6632.2009.04360.x]

[41] Bosland MC. Chemical and hormonal induction of prostate cancer in animal models. Urol Oncol 1996; 2: 103-10. [http://dx.doi.org/10.1016/S1078-1439(97)82840-2]

[42] Ricke W, Ishii K, Ricke EA, et al. Steroid hormones stimulate human prostate cancer progression and metastasis. Int J Cancer 2006; 118: 2123-31. [http://dx.doi.org/10.1002/ijc.21614]

[43] Ricke WA, McPherson SJ, Bianco JJ, Cunha GR, Wang Y, Risbridger GP. Prostatic hormonal carcinogenesis is mediated by in situ estrogen production and estrogen receptor alpha signaling. FASEB J 2008; 22: 1512-20. [http://dx.doi.org/10.1096/fj.07-9526com]

[44] Yu S, Zhang Y, Yuen MT, Zou C, Danielpour D, Chan FL. 17-Beta-estradiol induces neoplastic transformation in prostatic epithelial cells. Cancer Lett 2011; 304: 8-20. [http://dx.doi.org/10.1016/j.canlet.2011.01.003]

[45] Modugno F, Weissfeld JL, Trump DL, et al. Allelic variants of aromatase and androgen and estrogen receptors: toward a multigenic model of prostate cancer risk. Clin Cancer Res 2001; 7: 3092-6.

[46] Ellem SJ, Schmitt JF, Pedersen JS, Frydenberg M, Risbridger GP. Local aromatase expression in human prostate is altered in malignancy. J Clin Endocrinol Metab 2004; 89: 2431-41. [http://dx.doi.org/10.1210/jc.2003-030933]

[47] Montgomery B, Nelson PS, Vessella R, Kalhorn T, Hess D, Corey E. Estradiol suppresses tissue androgens and prostate cancer growth in castration resistant prostate cancer. BMC Cancer 2010; 10: 244-51. [http://dx.doi.org/10.1186/1471-2407-10-244] 
[48] Montgomery RB, Mostaghel EA, Vessella R, et al. Maintenance of intratumoral androgens in metastatic prostate cancer: a mechanism for castration-resistant tumor growth. Cancer Res 2008; 68: 4447-54. [http://dx.doi.org/10.1158/0008-5472.CAN-08-0249]

[49] Yu L, Wang CY, Shi J, et al. Estrogens promote invasion of prostate cancer cells in a paracrine manner through up-regulation of matrix metalloproteinase 2 in prostatic stromal cells. Endocrinology 2011; 152: 773-81. [http://dx.doi.org/10.1210/en.2010-1239]

[50] Setlur SR, Mertz KD, Hoshida Y, et al. Estrogen-dependent signaling in a molecularly distinct subclass of aggressive prostate cancer. J Natl Cancer Inst 2008; 100: 815-25.

[http://dx.doi.org/10.1093/jnci/djn150]

[51] Miro AM, Sastre-Serra J, Pons DG, Valle A, Roca P, Oliver J. 17beta-Estradiol regulates oxidative stress in prostate cancer cell lines according to ERalpha/ERbeta ratio. J Steroid Biochem Mol Biol 2011; 123: 133-9. [http://dx.doi.org/10.1016/j.jsbmb.2010.12.004]

[52] Nelson WG, Demarzo AM, Yegnasubramanian S. The diet as a cause of human prostate cancer. Cancer Treat Res 2014; 159 : 51-68. [http://dx.doi.org/10.1007/978-3-642-38007-5_4]

[53] Lichtenstein P, Holm NV, Verkasalo PK, et al. Environmental and heritable factors in the causation of cancer-analyses of cohorts of twins from Sweden, Denmark, and Finland. N Engl J Med 2000; 343: 78-85. [http://dx.doi.org/10.1056/NEJM200007133430201]

[54] Marks LS, Kojima M, Demarzo A, et al. Prostate cancer in native Japanese and Japanese-American men: effects of dietary differences on prostatic tissue. Urology 2004; 64: 765-71.

[http://dx.doi.org/10.1016/j.urology.2004.05.047]

[55] Diamanti-Kandarakis E, Bourguignon JP, Giudice LC, et al. Endocrine-disrupting chemicals: an Endocrine Society scientific statement. Endocr Rev 2009; 30: 293-342. [http://dx.doi.org/10.1210/er.2009-0002]

[56] Mahmoud AM, Yang W, Bosland MC. Soy isoflavones and prostate cancer: a review of molecular mechanisms. J Steroid Biochem Mol Biol 2014; 140: 116-32. [http://dx.doi.org/10.1016/j.jsbmb.2013.12.010]

[57] Cao Y, Calafat AM, Doerge DR, et al. Isoflavones in urine, saliva, and blood of infants: data from a pilot study on the estrogenic activity of soy formula. J Expo Sci Environ Epidemiol 2009; 19: 223-34. [http://dx.doi.org/10.1038/jes.2008.44]

[58] Morrison H, Savitz D, Semenciw R, et al. Farming and prostate cancer mortality. Am J Epidemiol 1993; $137: 270-80$.

[59] Meyer TE, Coker AL, Sanderson M, Symanski E. A case-control study of farming and prostate cancer in African-American and Caucasian men. Occup Environ Med 2007; 64: 155-60. [http://dx.doi.org/10.1136/oem.2006.027383]

[60] Alavanja MC, Samanic C, Dosemeci M, et al. Use of agricultural pesticides and prostate cancer risk in the Agricultural Health Study cohort. Am J Epidemiol 2003; 157: 800-14. [http://dx.doi.org/10.1093/aje/kwg040]

[61] Van Maele-Fabry G, Libotte V, Willems J, Lison D. Review and meta-analysis of risk estimates for prostate cancer in pesticide manufacturing workers. Cancer Causes Control 2006; 17: 353-73 [http://dx.doi.org/10.1007/s10552-005-0443-y]

[62] Kuroda M, Oikawa K, Ohbayashi T, et al. A dioxin sensitive gene, mammalian WAPL, is implicated in spermatogenesis. FEBS Lett 2005; 579: 167-72. [http://dx.doi.org/10.1016/j.febslet.2004.11.070]

[63] Benbrahim-Tallaa L, Liu J, Webber MM, Waalkes MP. Estrogen signaling and disruption of androgen metabolism in acquired androgenindependence during cadmium carcinogenesis in human prostate epithelial cells. Prostate 2007; 67: 135-45. [http://dx.doi.org/10.1002/pros.20479]

[64] Huff J, Lunn RM, Waalkes MP, Tomatis L, Infante PF. Cadmium-induced cancers in animals and in humans. Int J Occup Environ Health 2007; 13: 202-12. [http://dx.doi.org/10.1179/oeh.2007.13.2.202]

[65] Prince MM, Ruder AM, Hein MJ, et al. Mortality and exposure response among 14,458 electrical capacitor manufacturing workers exposed to polychlorinated biphenyls (PCBs). Environ Health Perspect 2006; 114: 1508-14. [http://dx.doi.org/10.1289/ehp.9175]

[66] Ritchie JM, Vial SL, Fuortes LJ, Guo H, Reedy VE, Smith EM. Organochlorines and risk of prostate cancer. J Occup Environ Med 2003; 45: 692-702. [http://dx.doi.org/10.1097/01.jom.0000071510.96740.0b]

[67] Charles LE, Loomis D, Shy CM, et al. Electromagnetic fields, polychlorinated biphenyls, and prostate cancer mortality in electric utility workers. Am J Epidemiol 2003; 157: 683-91. [http://dx.doi.org/10.1093/aje/kwg044] 
[68] Mahajan R, Blair A, Lynch CF, et al. Fonofos exposure and cancer incidence in the agricultural health study. Environ Health Perspect 2006; 114: 1838-42. [http://dx.doi.org/10.1289/ehp.8911]

[69] Usmani KA, Rose RL, Hodgson E. Inhibition and activation of the human liver microsomal and human cytochrome P450 3 A4 metabolism of testosterone by deployment-related chemicals. Drug Metab Dispos 2003; 31: 384-91. [http://dx.doi.org/10.1124/dmd.31.4.384]

[70] Usmani KA, Cho TM, Rose RL, Hodgson E. Inhibition of the human liver microsomal and human cytochrome P450 1A2 and 3 A4 metabolism of estradiol by deployment-related and other chemicals. Drug Metab Dispos 2006; 34: 1606-14. [http://dx.doi.org/10.1124/dmd.106.010439]

[71] Kester MH, Bulduk S, van Toor H, et al. Potent inhibition of estrogen sulfotransferase by hydroxylated metabolites of polyhalogenated aromatic hydrocarbons reveals alternative mechanism for estrogenic activity of endocrine disrupters. J Clin Endo Metab 2002; 87: $1142-50$. [http://dx.doi.org/10.1210/jcem.87.3.8311]

[72] Kester MH, Bulduk S, Tibboel D, et al. Potent inhibition of estrogen sulfotransferase by hydroxylated PCB metabolites: a novel pathway explaining the estrogenic activity of PCBs. Endocrinology 2000; 141: 1897-900. [http://dx.doi.org/10.1210/endo.141.5.7530]

[73] Alonso-Magdalena P, Ropero AB, Soriano S, et al. Bisphenol-A acts as a potent estrogen via non-classical estrogen triggered pathways. Mol Cell Endocrinol 2012; 355(2): 201-7. [http://dx.doi.org/10.1016/j.mce.2011.12.012]

[74] Zhou L, Le Roux G, Ducrot C, et al. Repression of class I transcription by cadmium is mediated by the protein phosphatase 2A. Nucleic Acids Res 2013; 41(12): 6087-97. [http://dx.doi.org/10.1093/nar/gkt335]

[75] Soto AM, Sonnenschein C, Chung KL, Fernandez MF, Olea N, Serrano FO. The E-SCREEN assay as a tool to identify estrogens: an update on estrogenic environmental pollutants. Environ Health Perspect 1995; 103(Suppl. 7): 113-22. [http://dx.doi.org/10.1289/ehp.95103s7113]

[76] Benbrahim-Tallaa L, Waalkes MP. Inorganic arsenic and human prostate cancer. Environ Health Perspect 2008; 116: 158-64. [http://dx.doi.org/10.1289/ehp.10423]

[77] Matthews J, Gustafsson JA. Estrogen receptor and aryl hydrocarbon receptor signaling pathways. Nucl Recept Signal 2006 ; 4 : e016.

[78] Shanle EK, Xu W. Endocrine disrupting chemicals targeting estrogen receptor signaling: identification and mechanisms of action. Chem Res Toxicol 2011; 24: 6-19. [http://dx.doi.org/10.1021/tx100231n]

[79] Dodds EC, Lawson W. Synthetic oestrogenic agents without phenanthrene nucleus. Nature 1936; 137: 996-7. [http://dx.doi.org/10.1038/137996a0]

[80] Stahlhut RW, Welshons WV, Swan SH. Bisphenol A data in NHANES suggest longer than expected half-life, substantial nonfood exposure, or both. Environ Health Perspect 2009; 117: 784-9. [http://dx.doi.org/10.1289/ehp.0800376]

[81] Calafat AM, Ye X, Wong LY, Reidy JA, Needham LL. Exposure of the U.S. population to bisphenol A and 4-tertiary-octylphenol: 2003-2004. Environ Health Perspect 2008; 116: 39-44. [http://dx.doi.org/10.1289/ehp.10753]

[82] Kuroda N, Kinoshita Y, Sun Y, et al. Measurement of bisphenol A levels in human blood serum and ascitic fluid by HPLC using a fluorescent labeling reagent. J Pharm Biol Anal 2003; 30: 1743-9. [http://dx.doi.org/10.1016/S0731-7085(02)00516-2]

[83] Lee YJ, Ryu HY, Kim HK, et al. Maternal and fetal exposure to bisphenol A in Korea. Reprod Toxicol 2008; 25: 413-9. [http://dx.doi.org/10.1016/j.reprotox.2008.05.058]

[84] Calafat AM, Weuve J, Ye X, et al. Exposure to bisphenol A and other phenols in neonatal intensive care unit premature infants. Environ Health Perspect 2009; 117: 639-44. [http://dx.doi.org/10.1289/ehp.0800265]

[85] Eddington AN, Ritter L. Predicting plasma concentrations of bisphenol A in children younger than 2 years of age after typical feeding schedules, using a physiologically based toxicokinetic model. Environ Health Perspect 2009; 117: 645-52. [http://dx.doi.org/10.1289/ehp.0800073]

[86] Ikezuki Y, Tsutsumi O, Takai Y, Kamiei Y, Taketani Y. Determination of bisphenol A concentrations in human biological fluids reveals significant early prenatal exposure. Hum Reprod 2002; 17: 2839-14. [http://dx.doi.org/10.1093/humrep/17.11.2839]

[87] Kuiper GG, Lemmen JG, Carlsson B, et al. Interaction of estrogenic chemicals and phytoestrogens with estrogen receptor b. Endocrinology 1998; 139: 4252-63.

[88] Lemmen JG, Arends RJ, van der Saag PT, van der Burg B. In vivo imaging of activated estrogen receptors in utero by estrogens and bisphenol A. Environ Health Perspect 2004; 112: 1544-9. [http://dx.doi.org/10.1289/ehp.7155] 
[89] Song KH, Lee K, Choi HS. Endocrine disruptor bisphenol A induces orphan nuclear receptor Nur77 gene expression and steroidogenesis in mouse testicular Leydig cells. Endocrinology 2002; 143: 2208-15. [http://dx.doi.org/10.1210/endo.143.6.8847]

[90] Walsh DE, Dockery P, Doolan CM. Estrogen receptor independent rapid non-genomic effects of environmental estrogens on [Ca2+]i in human breast cancer cells. Mol Cell Endocrinol 2005; 230: 23-30. [http://dx.doi.org/10.1016/j.mce.2004.11.006]

[91] Kurosawa T, Hiroi H, Tsutsumi O, et al. The activity of bisphenol A depends on both the estrogen receptor subtype and the cell type. Endocr J 2002; 49: 465-71. [http://dx.doi.org/10.1507/endocrj.49.465]

[92] Fan W, Yanase T, Morinaga H, et al. Atrazine-induced aromatase expression is SF-1 dependent: implications for endocrine disruption in wildlife and reproductive cancers in humans. Environ Health Perspect 2007; 115: 720-7. [http://dx.doi.org/10.1289/ehp.9758]

[93] Delfosse V, Grimaldi M, Pons JL, et al. Structural and mechanistic insights into bisphenols action provide guidelines for risk assessment and discovery of bisphenol A substitutes. Proc Natl Acad Sci USA 2012; 109: 14930-5. [http://dx.doi.org/10.1073/pnas.1203574109]

[94] Maffini MV, Rubin BS, Sonnenschein C, Soto AM. Endocrine disruptors and reproductive health: the case of bisphenol-A. Mol Cell Endocrinol 2006; 254-255: 179-86.

[http://dx.doi.org/10.1016/j.mce.2006.04.033]

[95] Keri R, Ho SM, Hunt PA, Knudsen KE, Soto AM, Prins GS. An Evaluation of evidence for the carcinogenic activity of bisphenol a: report of NIEHS expert panel on BPA. Reprod Toxicol 2007; 24: 240-52. [http://dx.doi.org/10.1016/j.reprotox.2007.06.008]

[96] Ho SM, Tang WY, Belmonte J, Prins GS. Developmental exposure to estradiol and bisphenol A (BPA) increases susceptibility to prostate carcinogenesis and epigenetically regulates phosphodiesterase type 4 variant (PDE4D4) in the rat prostate. Cancer Res 2006; 66: 5624-32. [http://dx.doi.org/10.1158/0008-5472.CAN-06-0516]

[97] Tarapore P, Ying J, Ouyang B, Burke B, Bracken B, Ho SM. Exposure to bisphenol A correlates with early-onset prostate cancer and promotes centrosome amplification and anchorage-independent growth in vitro. PLoS One 2014; 9: e90332. [http://dx.doi.org/10.1371/journal.pone.0090332]

[98] Wetherill YB, Fisher NL, Staubach A, Danielsen M, de Vere White RW, Knudsen KE. Xenoestrogen action in prostate cancer: pleiotropic effects dependent on androgen receptor status. Cancer Res 2005; 65: 54-65.

[99] Wetherill YB, Hess-Wilson JK, Comstock CE, et al. Bisphenol A facilitates bypass of androgen ablation therapy in prostate cancer. Mol Cancer Ther 2006; 5: 3181-90. [http://dx.doi.org/10.1158/1535-7163.MCT-06-0272]

[100] Kaufman JM, Vermeulen A. The decline of androgen levels in elderly men and its clinical and therapeutic implications. Endocr Rev 2005; 26: 833-76.

[http://dx.doi.org/10.1210/er.2004-0013]

[101] Ng JC, Wang J, Shraim A. A global health problem caused by arsenic from natural sources. Chemosphere 2003; 52: 1353-9. [http://dx.doi.org/10.1016/S0045-6535(03)00470-3]

[102] Hughes MF. Arsenic methylation, oxidative stress and cancer-is there a link? J Natl Cancer Inst 2009; 101: $1660-1$. [http://dx.doi.org/10.1093/jnci/djp437]

[103] Drobna Z, Naranmandura H, Kubachka KM, et al. Disruption of the arsenic $(+3$ oxidation state) methyltransferase gene in the mouse alters the phenotype for methylation of arsenic and affects distribution and retention of orally administered arsenate. Chem Res Toxicol 2009; 22: 1713-20. [http://dx.doi.org/10.1021/tx900179r]

[104] Gruber JJ, Zatechka DS, Sabin LR, et al. Ars2 links the nuclear cap-binding complex to RNA interference and cell proliferation. Cell 2009; 138: 328-39. [http://dx.doi.org/10.1016/j.cell.2009.04.046]

[105] Waalkes MP, Liu J, Diwan BA. Transplacental arsenic carcinogenesis in mice. Toxicol Appl Pharmacol 2007; 222: 271-80. [http://dx.doi.org/10.1016/j.taap.2006.12.034]

[106] Tokar EJ, Qu W, Waalkes MP. Arsenic, Stem cells and the developmental basis of adult cancer. Toxicol Sci 2011; 120 : S192-203. [http://dx.doi.org/10.1093/toxsci/kfq342]

[107] Waalkes MP, Liu J, Diwan BA. Transplacental arsenic carcinogenesis in mice. Toxicol Appl Pharmacol 2007; 222: 271-80. [http://dx.doi.org/10.1016/j.taap.2006.12.034]

[108] Knobeloch LM, Zierold KM, Anderson HA. Association of arsenic-contaminated drinking-water with prevalence of skin cancer in Wisconsin's Fox River Valley. J Health Popul Nutr 2006; 24: 206-13.

[109] Chen CJ, Kuo T, Wu M. Aresenic and cancers. Lancet 1988; 1: 414-5. [http://dx.doi.org/10.1016/S0140-6736(88)91207-X] 
[110] Chen CJ, Wang CJ. Ecological correlation between arsenic level in well water and age-adjusted mortality from malignant neoplasms. Cancer Res 1990; 50: 5470-4.

[111] Lewis DR, Southwick JW, Ouellet-Hellstrom R, Rench J, Calderon R. Drinking water aresenic in Utah: A cohort mortality study. Environ Health Perspect 1999; 107: 359-65.

[http://dx.doi.org/10.1289/ehp.99107359]

[112] Davey JC, Bodwell JE, Gosse JA, Hamilton J. Arsenic as an endocrine disruptor: effects of arsenic on estrogen receptor-mediated gene expression in vivo and in cell culture. Toxicol Sci 2007; 98: 75-86. [http://dx.doi.org/10.1093/toxsci/kfm013]

[113] Davey JC, Nomikos AP, Wungjiranirun M, et al. Arsenic as an endocrine disruptor: arsenic disrupts retinoic acid receptor-and thyroid hormone receptor-mediated gene regulation and thyroid hormone-mediated amphibian tail metamorphosis. Environ Health Perspect 2008; 116: 165-72. [http://dx.doi.org/10.1289/ehp.10131]

[114] Achanzar WE, Brambila EM, Diwan BA, Webber MM, Waalkes MP. Inorganic arsenite-induced malignant transformation of human prostate epithelial cells. Environ Health Natl Camcer Inst 2002; 94: 1888-91. [http://dx.doi.org/10.1093/jnci/94.24.1888]

[115] Benbrahim-Tallaa L, Waterland RA, Styblo M, Achanzar WE, Webber MM, Waalkes MP. Molecular events associated with arsenic-induced malignant transformation of human prostatic epithelial cells: aberrant genomic DNA methylation and K-ras oncogene activation. Toxicol Appl Pharmacol 2005; 206: 1134-9. [http://dx.doi.org/10.1016/j.taap.2004.11.017]

[116] Benbrahim-Tallaa L, Webber MM, Waalkes MP. Mechanisms of acquired androgen independence during arsenic-induced malignant transformation of human prostate epithelial cells. Environ Health Perspect 2007; 115: 2.

[117] Tokar EJ, Qu W, Liu J, et al. Arsenic-specific stem cell selection during malignant transformation. Environ Health Natl Camcer Inst 2010; 102: 638-49. [http://dx.doi.org/10.1093/jnci/djq093]

[118] Tokar EJ, Diwan BA, Waalkes MP. Arsenic exposure transforms human epithelial stem/progenitor cells into a cancer stem-like phenotype. Environ Health Perspect 2010; 118: 108-15.

[119] Tokar EJ, Benbrahim-Tallaa L, Ward JM, Lunn R, Sams RL, Waalkes MP. Cancer in experimental animals exposed to arsenic and arsenic compounds. Crit Rev Toxicol 2010; 40: 912-27.

[http://dx.doi.org/10.3109/10408444.2010.506641]

[120] Xu Y, Tokar EJ, Sun Y, Waalkes MP. Arsenic-transformed malignant prostate epithelia can convert noncontiguous normal stem cells into an oncogenic phenotype. Environ Health Perspect 2012; 120: 865-71. [http://dx.doi.org/10.1289/ehp.1204987]

[121] Singh KP, Kumari R, Treas J, DuMond JW. Chronic exposure to arsenic causes increased cell survival, DNA damage, and increased expression of mitochondrial transcription factor A (mtTFA) in human prostate epithelial cells. Chem Res Toxicol 2011; $24: 340-9$. [http://dx.doi.org/10.1021/tx1003112]

[122] Rossman TG. Mechanism of arsenic carcinogenesis: an integrated approach. Mutat Res 2003; 533: 37-65. [http://dx.doi.org/10.1016/j.mrfmmm.2003.07.009]

[123] Kojima C, Ramirez DC, Tokar EJ, et al. Requirement of arsenic biomethylation for oxidative DNA damage. Environ Health Natl Camcer Inst 2009; 101: 1670-81.

[http://dx.doi.org/10.1093/jnci/djp414]

[124] Treas JN, Tyagi T, Singh KP. Effects of chronic exposure to arsenic and estrogen on epigenetic regulatory genes expression and epigenetic code in human prostate epithelial cells. PLoS One 2012; 7: e43880. [http://dx.doi.org/10.1371/journal.pone.0043880]

[125] Treas J, Tyagi T, Singh KP. Chronic exposure to arsenic, estrogen, and their combination causes increased growth and transformation in human prostate epithelial cells potentially by hypermethylation-mediated silencing of MLH1. Prostate 2013; 73: 1660-72.

[126] Ngalame NN, Tokar EJ, Person RJ, Xu Y, Waalkes MP. Aberrant microRNA expression likely controls RAS oncogene activation during malignant transformation of human prostate epithelial and stem cells by arsenic. Toxicol Sci 2014; 138: 268-77. [http://dx.doi.org/10.1093/toxsci/kfu002]

[127] Cunha G, Fujii H, Neubauer B, Shannon J, Sawyer L, Reese B. Epithelial-mesenchymal interactions in prostatic development. I. Morphological observations of prostatic induction by urogenital sinus mesenchyme in epithelium of the adult rodent urinary bladder. J Cell Biol 1983; 96: 1662-70 [http://dx.doi.org/10.1083/jcb.96.6.1662]

[128] Cunha GR. The role of androgens in the epithelio-mesenchymal interactions involved in prostatic morphogenesis in embryonic mice. Anat Rec 1973; 175: 87-96. [http://dx.doi.org/10.1002/ar.1091750108]

[129] Cunha GR, Donjacour AA, Cooke PS, et al. The endocrinology and developmental biology of the prostate. Endocr Rev 1987; 8: 338-63. [http://dx.doi.org/10.1210/edrv-8-3-338] 
[130] Long RM, Morrissey C, Fitzpatrick JM, Watson RW. Prostate epithelial cell differentiation and its relevance to the understanding of prostate cancer therapies. Clin Sci (Lond) 2005; 108: 1-11. [http://dx.doi.org/10.1042/CS20040241]

[131] Prins GS. Reproductive Issues and the Aging Male. In: Haseltine F, Paulsen C, Wang C, Eds. Embryonic, Inc. New York 1993 ; pp. 101-12.

[132] Prins GS, Putz O. Molecular signaling pathways that regulate prostate gland development. Differentiation 2008; 76 : 641-59. [http://dx.doi.org/10.1111/j.1432-0436.2008.00277.x]

[133] Chung LW, Cunha GR. Stromal-epithelial interactions: II. Regulation of prostatic growth by embryonic urogenital sinus mesenchyme. Prostate 1983; 4: 503-11. [http://dx.doi.org/10.1002/pros.2990040509]

[134] Isaacs JT, Barrack ER, Isaacs WB, Coffey DS. The Prostatic Cell: Structure and function In: Alan R, Ed. New York: Liss, Inc 1981; pp. 1-24. Part A.

[PMID: 7200232]

[135] Wang Y, Hayward SW, Cao M, Thayer K, Cunha GR. Cell differentiation lineage in the prostate. Differentiation 2001; 68: 270-9. [http://dx.doi.org/10.1046/j.1432-0436.2001.680414.x]

[136] Bhatia-Gaur R, Donjacour AA, Sciavolino PJ, et al. Roles for Nkx3.1 in prostate development and cancer. Genes Dev 1999; 13 : 966-77. [http://dx.doi.org/10.1101/gad.13.8.966]

[137] Hayward S, Cunha G, Dahiya R. Normal development and carcinogenesis of the prostate; A unifying hypothesis. Ann N Y Acad Sci 1996; 784: 50-62. [http://dx.doi.org/10.1111/j.1749-6632.1996.tb16227.x]

[138] Wang H, McKnight NC, Zhang T, Lu ML, Balk SP, Yuan X. SOX9 is expressed in normal prostate basal cells and regulates androgen receptor expression in prostate cancer cells. Cancer Res 2007; 67: 528-36. [http://dx.doi.org/10.1158/0008-5472.CAN-06-1672]

[139] Rumpold H, Heinrich E, Untergasser G, et al. Neuroendocrine differentiation of human prostatic primary epithelial cells in vitro. Prostate 2002; 53: 101-8.

[http://dx.doi.org/10.1002/pros.10129]

[140] van Leenders G, van Balken B, Aalders T, Hulsbergen-van de Kaa C, Ruiter D, Schalken J. Intermediate cells in normal and malignant prostate epithelium express c-MET: implications for prostate cancer invasion. Prostate 2002; 51: 98-107. [http://dx.doi.org/10.1002/pros.10073]

[141] Garraway IP, Sun W, Tran CP, et al. Human prostate sphere-forming cells represent a subset of basal epithelial cells capable of glandular regeneration in vivo. Prostate 2010; 70: 491-501.

[142] Garraway LA, Lin D, Signoretti S, et al. Intermediate basal cells of the prostate: in vitro and in vivo characterization. Prostate 2003; 55: 206-18. [http://dx.doi.org/10.1002/pros.10244]

[143] Goldstein AS, Lawson DA, Cheng D, Sun W, Garraway IP, Witte ON. Trop2 identifies a subpopulation of murine and human prostate basal cells with stem cell characteristics. Proc Natl Acad Sci USA 2008; 105: 20882-7. [http://dx.doi.org/10.1073/pnas.0811411106]

[144] Isaacs JT. Prostate stem cells and benign prostatic hyperplasia. Prostate 2008; 68: 1025-34. [http://dx.doi.org/10.1002/pros.20763]

[145] Kasper S. Characterizing the prostate stem cell. J Urol 2007; 178: 375. [http://dx.doi.org/10.1016/j.juro.2007.05.031]

[146] Lawson DA, Zong Y, Memarzadeh S, Xin L, Huang J, Witte ON. Basal epithelial stem cells are efficient targets for prostate cancer initiation. Proc Natl Acad Sci USA 2010; 107: 2610-5. [http://dx.doi.org/10.1073/pnas.0913873107]

[147] Leong KG, Wang BE, Johnson L, Gao WQ. Generation of a prostate from a single cell. Nature 2008; 456: 804-8. [http://dx.doi.org/10.1038/nature07427]

[148] Liu J, Pascal LE, Isharwal S, et al. Regenerated luminal epithelial cells are derived from preexisting luminal epithelial cells in adult mouse prostate. Mol Endocrinol 2011; 25: 1849-57. [http://dx.doi.org/10.1210/me.2011-1081]

[149] Xin L, Lukacs RU, Lawson DA, Cheng D, Witte ON. Self-renewal and multilineage differentiation in vitro from murine prostate stem cells. Stem Cells 2007; 25: 2760-9. [http://dx.doi.org/10.1634/stemcells.2007-0355]

[150] Cunha GR. Epithelial-stromal interactions in development of the urogenital tract. Int Rev Cytol 1976; 47: 137-94. [http://dx.doi.org/10.1016/S0074-7696(08)60088-1]

[151] Cunha GR. Progress in cancer research and therapy. In: Bresciani F, Ed. New York: Raven Press 1984; Vol. 31: pp. 121-8.

[152] Tsujimura A, Koikawa Y, Salm S, et al. Proximal location of mouse prostate epithelial stem cells: a model of prostatic homeostasis. JCB 2002; 157: 1257-65 
[http://dx.doi.org/10.1083/jcb.200202067]

[153] Goto K, Salm SN, Xiong X, et al. Proximal prostatic stem cells are programmed to regenerate a proximal-distal ductal axis. Stem Cells 2006; 24: 1859-68. [http://dx.doi.org/10.1634/stemcells.2005-0585]

[154] Hudson DL. Epithelial stem cells in human prostate growth and disease. Prostate Cancer Prostatic Dis 2004; 7: 188-94. [http://dx.doi.org/10.1038/sj.pcan.4500745]

[155] De Marzo A, Nelson W, Meeker A, Coffey D. Stem cell features of benign and malignant prostate epithelial cells. J Urol 1998 ; $160: 2381-92$. [http://dx.doi.org/10.1016/S0022-5347(01)62196-7]

[156] Burger PE, Xiong X, Coetzee S, et al. Sca-1 expression identifies stem cells in the proximal region of prostatic ducts with high capacity to reconstitute prostatic tissue. Proc Natl Acad Sci USA 2005; 102: 180-5. [http://dx.doi.org/10.1073/pnas.0502761102]

[157] Morrison SJ, Kimble J. Assymetric and symetric stem cell divisions in development and cancer. Nature 2006; 441: 1068-74 [http://dx.doi.org/10.1038/nature04956]

[158] Scaffidi P, Misteli T. In vitro generation of human cells with cancer stem cell properties. Nat Cell Biol 2011; 19: 1051-6. [http://dx.doi.org/10.1038/ncb2308]

[159] Tomasetti C, Levy D. Role of symmetric and asymmetric division of stem cells in developing drug resistance. Proc Natl Acad Sci USA 2010; 107: 16766-71.

[http://dx.doi.org/10.1073/pnas.1007726107]

[160] Peehl DM. Prostate Cancer Methods and Protocols. In: Russell PJ, Kingsley EA, Eds. Totowa, NJ: Humana Press 2003; pp. 41-57.

[161] Lukacs RU, Goldstein AS, Lawson DA, Cheng D, Witte ON. Isolation, cultivation and characterization of adult murine prostate stem cells. Nat Protoc 2010; 5: 702-13. [http://dx.doi.org/10.1038/nprot.2010.11]

[162] Xin L, Lawson DA, Witte ON. The Sca-1 cell surface marker enriches for a prostate-regenerating cell subpopulation that can initiate prostate tumorigenesis. Proc Natl Acad Sci USA 2005; 102: 6942-7. [http://dx.doi.org/10.1073/pnas.0502320102]

[163] Collins AT, Habib FK, Maitland NJ, Neal DE. Identification and isolation of human prostate epithelial stem cells based on alpha(2)beta(1)integrin expression. J Cell Sci 2001; 114: 3865-72.

[164] The role of CD133 in normal human prostate stem cells and malignant cancer-initiating cells. Cancer Res 2008; 68: 9703-11. [http://dx.doi.org/10.1158/0008-5472.CAN-08-3084]

[165] Richardson GD, Robson CN, Lang SH, Neal DE, Maitland NJ, Collins AT. CD133, a novel marker for human prostatic epithelial stem cells. J Cell Sci 2003; 117: 3539-45. [http://dx.doi.org/10.1242/jcs.01222]

[166] Ding XW, Wu JH, Jiang CP. ABCG2: a potential marker of stem cells and novel target in stem cell and cancer therapy. Life Sci 2010; 86: 631-7. [http://dx.doi.org/10.1016/j.lfs.2010.02.012]

[167] Zhou S, Schuetz JD, Bunting KD, et al. The ABC transporter Bcrp1/ABCG2 is expressed in a wide variety of stem cells and is a molecular determinant of the side-population phenotype. Nat Med 2001; 7: 1028-34. [http://dx.doi.org/10.1038/nm0901-1028]

[168] Brown MD, Gilmore PE, Hart CA, et al. Characterization of benign and malignant prostate epithelial Hoeschst 33342 side populations. Prostate 2007; 67: 1384-96.

[http://dx.doi.org/10.1002/pros.20620]

[169] Lukacs RU, Goldstein AS, Lawson DA, Cheng D, Witte ON. Isolation, cultivation and characterization of adult murine prostate stem cells. Nat Protoc 2010; 5: 702-13. [http://dx.doi.org/10.1038/nprot.2010.11]

[170] Lang SH, Stark M, Collins A, Paul AP, Stower MJ, Maitland NJ. Experimental prostate morphogenesis in response to stroma and three dimensional matrigel culture. Cell Growth Differ 2001; 12: 631-40.

[171] Hudson DL. Epithelial cell culture protocols. In: Wise C, Ed. Totowa, New Jersey: Humana Press 2002; pp. 77-84.

[172] Mollard R, Shyselinck N, Wendling O, Chamson P, Mark M. Stage-dependent responses of the developing lung to retinoic acid signaling. Int J Dev Biol 2000; 44: 457-62.

[173] Lemmen JG, Arends RJ, van Boxtel AL, van der Saag PT, van der Burg B. Tissue- and time-dependent estrogen receptor activation in estrogen reporter mice. J Mol Endocrinol 2004; 32: 689-701. [http://dx.doi.org/10.1677/jme.0.0320689]

[174] Barba M, Yang L, Schunemann HJ, et al. Urinary estrogen metabolites and prostate cancer: a case-control study and meta-analysis. J Exp Clin Cancer Res 2009; 28: 135.

[http://dx.doi.org/10.1186/1756-9966-28-135] 
[175] Weiner JM, Marmorston J, Stern E, Hopkins CE. Urinary hormone metabolites in cancer and benign hyperplasia of the prostate: a multivariate statistical analysis. Ann N Y Acad Sci 1966; 125: 974-83. [http://dx.doi.org/10.1111/j.1749-6632.1966.tb45449.x]

[176] Steiner MS, Pound CR. Phase IIA clinical trial to test the efficacy and safety of Toremifene in men with high-grade prostatic intraepithelial neoplasia. Clin Prostate Cancer 2003; 2: 24-31. [http://dx.doi.org/10.3816/CGC.2003.n.009]

[177] Lowsley OS. The development of the human prostate gland with reference to the development of other structures at the neck of the urinary bladder. Am J Anat 1912; 13: 299-348. [http://dx.doi.org/10.1002/aja.1000130303]

[178] Hayward SW, Wang Y, Cao M, et al. Malignant transformation in a nontumorigenic human prostatic epithelial cell line. Cancer Res 2001; 61: 8135-42.

[179] Henderson B, Ross R, Pike M, Casagrande J. Endogenous hormones as a major factor in human cancer. Cancer Res 1982; 42 : 3232-9.

[180] Henderson BE, Bernstein L, Ross RK, Depue RH, Judd HL. The early in utero oestrogen and testosterone environment of blacks and whites: potential effects on male offspring. Br J Cancer 1988; 57: 216-8. [http://dx.doi.org/10.1038/bjc.1988.46]

[181] Fouse SD, Shen Y, Pellegrini M, et al. Promoter CpG methylation contributes to ES cell gene regulation in parallel with Oct4/Nanog, PcG complex, and histone H3 K4/K27 trimethylation. Cell Stem Cell 2008; 2: 160-9. [http://dx.doi.org/10.1016/j.stem.2007.12.011]

[182] Blackwood JK, Williamson SC, Greaves LC, et al. In situ lineage tracking of human prostatic epithelial stem cell fate reveals a common clonal origin for basal and luminal cells. J Pathol 2011; 225: 181-8. [http://dx.doi.org/10.1002/path.2965]

[183] Goldstein AS, Huang J, Guo C, Garraway IP, Witte ON. Identification of a cell of origin for human prostate cancer. Science 2010; 329: $568-71$ [http://dx.doi.org/10.1126/science.1189992]

[184] Stoyanova T, Cooper AR, Drake JM, et al. Prostate cancer originating in basal cells progresses to adenocarcinoma propagated by luminal-like cells. Proc Natl Acad Sci USA 2013; 110: 20111-6. [http://dx.doi.org/10.1073/pnas.1320565110]

[185] Gu G, Yuan J, Wills M, Kasper S. Prostate cancer cells with stem cell characteristics reconstitute the original human tumor in vivo. Cancer Res 2007; 67: 4708-15. [http://dx.doi.org/10.1158/0008-5472.CAN-06-4608]

[186] Smith S, Neaves W, Teitelbaum S. Adult versus embryonic stem cells: Treatments. Science 2007; 316(5830) [http://dx.doi.org/10.1126/science.316.5830.1422b]

[187] Maitland NJ, Collins AT. Prostate cancer stem cells: a new target for therapy. J Clin Oncol 2008; 26: $2862-70$. [http://dx.doi.org/10.1200/JCO.2007.15.1472]

[188] Oldridge EE, Pellacani D, Collins AT, Maitland NJ. Prostate cancer stem cells: Are they androgen-responseive? Mol Cell Endocrinol 2012; 360(1-2): 14-24. [http://dx.doi.org/10.1016/j.mce.2011.07.008]

[189] Cocciadiferro L, Miceli V, Kang KS, Polito LM, Trosko JE, Carruba G. Profiling cancer stem cells in androgen-responsive and refractory human prostate tumor cell lines. Ann N Y Acad Sci 2009; 1155: 257-62. [http://dx.doi.org/10.1111/j.1749-6632.2009.03696.x]

[190] Liu AY, True L. Characterization of prostate cell types by CD cell surface molecules. Am J Pathol 2002; 160: 37-43. [http://dx.doi.org/10.1016/S0002-9440(10)64346-5]

[191] Cheng AS, Culhane AC, Chan MW, et al. Epithelial progeny of estrogen-exposed breast progenitor cells display a cancer-like methylome. Cancer Res 2008; 68: 1786-96.

[http://dx.doi.org/10.1158/0008-5472.CAN-07-5547]

[192] Cairns J. Mutation selection and the natural history of cancer. Nature 1975; 255: 197-200. [http://dx.doi.org/10.1038/255197a0]

[193] Cairns J. Cancer and the immortal strand hypothesis. Genetics 2006; 174: 1069-72. [http://dx.doi.org/10.1534/genetics.104.66886]

[194] Pu Y, Huang L, Prins GS. Neonatal estrogen exposure alters epithelial differentiation in rat prostate through down regulation of Hoxb-13. J Androl 2004; 25(81)(Suppl. S) Ch. 129. Available from: http://eurekamag.com/research/035/374/035374278.php

[195] Giangreco AA, Vaishnav A, Wagner D, et al. Tumor suppressor microRNAs, miR-100 and -125b, are regulated by 1,25-dihydroxyvitamin D in primary prostate cells and in patient tissue. Cancer Prev Res (Phila) 2013; 6: 483-94. [http://dx.doi.org/10.1158/1940-6207.CAPR-12-0253]

[196] Goldstein AS, Staoyanova T, Witte ON. Primitive origins of prostate cancer: In vivo evidence for prostate-regenerating cells and prostatecancer initiating cells. Mol Oncol 2010; 4: 385-96. 
[http://dx.doi.org/10.1016/j.molonc.2010.06.009]

[197] Newbold RR, Padilla-Banks E, Jefferson WN. Adverse effects of the model environmental estrogen diethylstilbestrol are transmitted to subsequent generations. Endocrinology 2006; 147: S11-7. [http://dx.doi.org/10.1210/en.2005-1164]

Received: May 26, 2014

Revised: April 12,2015

Accepted: June 5, 2015

(C) Hu et al.; Licensee Bentham Open.

This is an open access article licensed under the terms of the Creative Commons Attribution-Non-Commercial 4.0 International Public License (CC BY-NC 4.0) (https://creativecommons.org/licenses/by-nc/4.0/legalcode), which permits unrestricted, non-commercial use, distribution and reproduction in any medium, provided the work is properly cited. 